\title{
The global marine phosphorus cycle: sensitivity to oceanic circulation
}

\author{
C. P. Slomp and P. Van Cappellen \\ Department of Earth Sciences - Geochemistry, Faculty of Geosciences, Utrecht University, P.O. Box 80021, 3508 TA \\ Utrecht, The Netherlands
}

Received: 4 September 2006 - Published in Biogeosciences Discuss.: 5 October 2006

Revised: 8 January 2007 - Accepted: 20 February 2007 - Published: 22 February 2007

\begin{abstract}
A new mass balance model for the coupled marine cycles of phosphorus $(\mathrm{P})$ and carbon $(\mathrm{C})$ is used to examine the relationships between oceanic circulation, primary productivity, and sedimentary burial of reactive $\mathrm{P}$ and particulate organic C (POC), on geological time scales. The model explicitly represents the exchanges of water and particulate matter between the continental shelves and the open ocean, and it accounts for the redox-dependent burial of POC and the various forms of reactive $\mathrm{P}$ (iron(III)-bound P, particulate organic $\mathrm{P}$ (POP), authigenic calcium phosphate, and fish debris). Steady state and transient simulations indicate that a slowing down of global ocean circulation decreases primary production in the open ocean, but increases that in the coastal ocean. The latter is due to increased transfer of soluble P from deep ocean water to the shelves, where it fuels primary production and causes increased reactive $\mathrm{P}$ burial. While authigenic calcium phosphate accounts for most reactive $\mathrm{P}$ burial ocean-wide, enhanced preservation of fish debris may become an important reactive $\mathrm{P}$ sink in deep-sea sediments during periods of ocean anoxia. Slower ocean circulation globally increases POC burial, because of enhanced POC preservation under anoxia in deep-sea depositional environments and higher primary productivity along the continental margins. In accordance with geological evidence, the model predicts increased accumulation of reactive $\mathrm{P}$ on the continental shelves during and following periods of ocean anoxia.
\end{abstract}

\section{Introduction}

Phosphorus $(\mathrm{P})$ is a key nutrient element in marine biogeochemistry. Consequently, insight into the various forcings and functioning of the marine $\mathrm{P}$ cycle is needed to under-

Correspondence to: C. P. Slomp

(slomp@geo.uu.nl) stand long-term variations in marine biological activity, atmospheric composition and climate (Holland, 1984; Van Cappellen and Ingall, 1996; Petsch and Berner, 1998; Bjerrum and Canfield, 2002). Important forcings include the supply of reactive $\mathrm{P}$ from the continents, oceanic circulation and sea level fluctuations (Föllmi, 1996; Compton et al., 2000; Handoh and Lenton, 2003; Wallmann, 2003; Bjerrum et al., 2006).

Upward transport of nutrient-rich water sustains biological activity in marine surface waters. Vertical mixing, however, also controls the ventilation of the deeper ocean waters, which in turn has a major effect on the sedimentary burial of phosphorus. An expansion of anoxic bottom waters in the deep ocean, as a result of decreased vertical mixing, increases the concentration of dissolved phosphate below the thermocline, because of a lower burial efficiency of reactive phosphorus phases (Ingall et al., 1993; Ingall and Jahnke, 1997; Colman and Holland, 2000; Slomp et al., 2002). The increased concentrations of soluble P may offset the drop in vertical mixing rates, possibly even causing phosphoruslimited ocean primary production to increase during periods of ocean stagnation (Van Cappellen and Ingall, 1994; Wallmann, 2003). Hence, redox-sensitive burial of reactive $P$ in marine sediments has been proposed as a feedback mechanism involved in the occurrence of oceanic anoxic events, or OAEs (Kuypers, 2001; Nederbragt et al., 2004).

Previous global-scale modeling studies of the response of the coupled marine cycles of carbon (C) and phosphorus to changes in oceanic circulation and water column ventilation do not explicitly account for the role of the continental margins (Van Cappellen and Ingall, 1994; Wallmann, 2003; Nederbragt et al., 2004). Yet, in the modern ocean, up to $70-90 \%$ of burial of organic matter and reactive phosphorus takes place in nearshore environments and on the continental shelves (Berner, 1982; Ruttenberg, 1993; Howarth et al., 1995). This oceanic compartment therefore exerts a major influence on land-ocean interactions, nutrient recycling and

Published by Copernicus GmbH on behalf of the European Geosciences Union. 


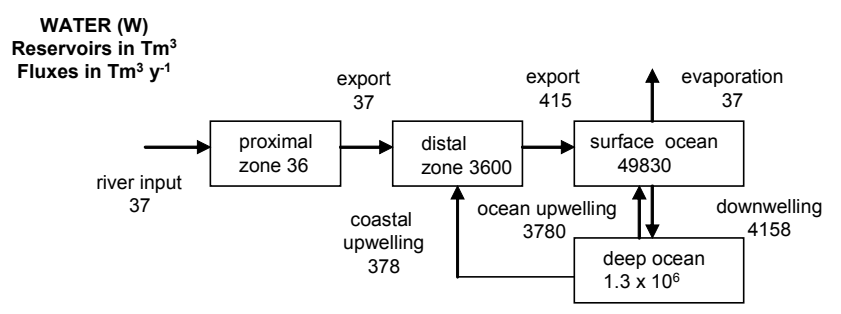

Fig. 1. Modern, steady-state oceanic water (W) cycle. Reservoirs in $\mathrm{Tm}^{3}$; Fluxes in $\mathrm{Tm}^{3} \mathrm{y}^{-1}$.

global marine productivity (Walsh, 1991; Mackenzie et al., 1993; Wollast, 1993; Ver et al., 1999).

In this paper, we analyze the sensitivity of the coupled biogeochemical cycles of $\mathrm{P}$ and $\mathrm{C}$ to changes in oceanic circulation, using a 4-box ocean model where exchanges of water and particulate matter between the continental shelves and the open ocean are explicitly represented. The results are compared to those obtained with the 1-box ocean model of Van Cappellen and Ingall (1996), in order to assess the respective roles of the continental margins and the open ocean in long-term variations of marine biological productivity. In particular, the simulations show that changes in oceanic circulation may induce marked shifts in primary productivity and burial of reactive phosphorus between the coastal and open ocean domains.

\section{Model description}

The 4-box ocean model represents the cycling of reactive forms of $\mathrm{P}$ and includes the relevant parts of the water, carbon (C) and oxygen $\left(\mathrm{O}_{2}\right)$ cycles. Initial reservoir sizes and steady state fluxes are estimated for the modern, pre-anthropogenic ocean system. The model combines and extends concepts from previous modeling studies on global nutrient cycling (Mackenzie et al., 1993; Van Cappellen and Ingall, 1994; Ver et al., 1999; Rabouille et al., 2001).

\subsection{Water cycle}

The continental margins and the open ocean are each divided into two zones, giving a total of four physical ocean boxes (Fig. 1): (1) the proximal zone, which comprises the part of the coastal ocean directly influenced by river input and includes large bays, the open water part of estuaries, deltas, inland seas, and coastal salt marshes, (2) the distal zone, where element recycling and upwelling are quantitatively more important than river input and which includes the open continental shelves (average water depth $130 \mathrm{~m}$ ), (3) the mixed surface layer of the open ocean (average depth $150 \mathrm{~m}$ ) and (4) the deep ocean.

The amount of water in the proximal and distal ocean reservoirs is relatively small compared to that of the open ocean (Table 1). All water is assumed to enter the proximal coastal zone through rivers and to leave the ocean through evaporation (Fig. 1). Initial river and upwelling water fluxes are obtained from the literature (Table 1); all other water fluxes are then defined by mass balance constraints. The large water fluxes in Fig. 1 reflect the vigorous thermohaline circulation characterizing the present-day ocean.

Changes in circulation are imposed by multiplying the water fluxes representing coastal and oceanic upwelling by the non-dimensional parameters $f_{\mathrm{mix}}^{\mathrm{cst}}$ and $f_{\mathrm{mix}}^{\text {oce }}$, respectively. The parameters are initially set to 1 . Because the total volume of water in the oceans is kept constant, changes in $f_{\text {mix }}^{\text {cst }}$ and

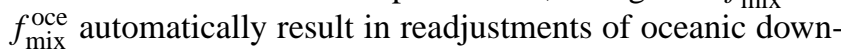
welling and the water flow from the distal coastal ocean to the open ocean. The simulations presented in this paper focus on the biogeochemical consequences of reduced global scale ocean circulation, that is when $f_{\text {mix }}^{\text {cst }}$ and $f_{\text {mix }}^{\text {oce }}$ become smaller than 1.

\section{$2.2 \mathrm{C}, \mathrm{O}_{2}$ and $\mathrm{P}$ cycles}

Particulate organic carbon (POC) is the only carbon phase included in the model; it is entirely associated with living and detrital marine biomass (Table 2). Terrestrial organic matter entering the oceans is assumed to be refractory, and is not explicitly represented in the model. The processes affecting the water column POC masses are primary production, mineralization, burial in sediment and transfer between ocean reservoirs (Table 2).

For dissolved oxygen $\left(\mathrm{O}_{2}\right)$, only changes in the content of the deep oceanic reservoir are considered (Table 3). This implies that efficient exchange of oxygen with the atmosphere is assumed to keep shelf areas and surface waters fully oxic during periods of increased primary productivity (Rabouille et al., 2001) or decreased oceanic circulation. Deep ocean $\mathrm{O}_{2}$ is replenished through downwelling and removed through upwelling and aerobic respiration (Table 3). When $\mathrm{O}_{2}$ is depleted, anaerobic organic matter degradation leads to the formation of reduced substances (RS, in units of oxygen equivalents). These reduced substances (e.g. sulfides) can be removed through burial as solid phases in the sediment, upwelling to surface waters or oxidation by downwelling $\mathrm{O}_{2}$.

Reactive phosphorus in the water column is present under three forms: particulate organic phosphorus (POP), biogenic calcium phosphate in fish hard parts (Fish-P), and soluble reactive phosphorus (SRP) (Fig. 2; Table 4). All POP is assumed to be associated with living marine biomass or biogenic detritus. SRP comprises both dissolved organic and inorganic $\mathrm{P}$. The processes affecting the marine cycle of reactive $\mathrm{P}$ are river input, primary production, mineralization of biomass, production and dissolution of fish hard parts, transfer among water column reservoirs, and removal into the sediments. The latter includes burial of POP and Fish-P that escape degradation, but also burial of $\mathrm{P}$ that is bound to authigenic ferric iron oxides $(\mathrm{FeP})$ or that has precipitated as 
Table 1. Reservoir sizes and fluxes of the modern, steady state oceanic water cycle. The mean water depths of the ocean reservoirs are $20 \mathrm{~m}$ (proximal zone), $130 \mathrm{~m}$ (distal zone), $150 \mathrm{~m}$ (open ocean mixed surface layer) and $3730 \mathrm{~m}$ (deep ocean).

\begin{tabular}{|c|c|c|c|}
\hline \multicolumn{4}{|c|}{ Reservoirs } \\
\hline W1 & proximal coastal zone & $36 \mathrm{Tm}^{3}$ & {$[1]$} \\
\hline W2 & distal coastal zone & $3600 \mathrm{Tm}^{3}$ & {$[1]$} \\
\hline W3 & surface layer open ocean & $49830 \mathrm{Tm}^{3}$ & depth $\times$ surface area [2] \\
\hline W4 & deep ocean & $1.3 \times 10^{6} \mathrm{Tm}^{3}$ & $\begin{array}{l}\text { total ocean volume } \\
-(\mathrm{W} 1+\mathrm{W} 2+\mathrm{W} 3)\end{array}$ \\
\hline \multicolumn{4}{|c|}{ Fluxes } \\
\hline WF1 & river flow entering $\mathrm{W} 1$ & $37 \mathrm{Tm}^{3} \mathrm{y}^{-1}$ & [3] \\
\hline WF2 & flow from $\mathrm{W} 1$ to $\mathrm{W} 2$ & $37 \mathrm{Tm}^{3} \mathrm{y}^{-1}$ & $=\mathrm{WF} 1$ \\
\hline WF3 & flow from $\mathrm{W} 2$ to $\mathrm{W} 3$ & $415 \mathrm{Tm}^{3} \mathrm{y}^{-1}$ & $=\mathrm{WF} 2+\mathrm{WF} 6$ \\
\hline WF4 & downwelling (W3 to W4) & $4158 \mathrm{Tm}^{3} \mathrm{y}^{-1}$ & $=\mathrm{WF} 5+\mathrm{WF} 6$ \\
\hline WF5 & oceanic upwelling (W4 to W3) & $3780 \mathrm{Tm}^{3} \mathrm{y}^{-1}$ & $120 \mathrm{~Sv}[4]$ \\
\hline WF6 & coastal upwelling (W4 to W2) & $378 \mathrm{Tm}^{3} \mathrm{y}^{-1}$ & $12 \mathrm{~Sv}[4]$ \\
\hline WF7 & evaporation from W3 & $37 \mathrm{Tm}^{3} \mathrm{y}^{-1}$ & $=\mathrm{WF} 1$ \\
\hline
\end{tabular}

[1] Rabouille et al. (2001); [2] surface area open ocean = 332.2 $\mathrm{Tm}^{2}$ (Butcher et al., 1992); [3] Berner and Berner (1996); [4] Brink et al. (1995).

Table 2. Steady state reservoir masses and fluxes of the modern, pre-anthropogenic marine carbon cycle. Some of the estimates require reservoir masses and fluxes given in Tables 1,3 and 4.

\begin{tabular}{|c|c|c|c|}
\hline \multicolumn{4}{|c|}{ Reservoirs } \\
\hline $\mathrm{C} 1$ & POC proximal coastal zone & $4.5 \mathrm{Tmol}$ & $=\mathrm{CF} 4 \times(\mathrm{W} 1 / \mathrm{WF} 2)$ \\
\hline $\mathrm{C} 2$ & POC distal coastal zone & 243 Tmol & $=\mathrm{P} 5 \times 106$ \\
\hline $\mathrm{C} 3$ & POC surface open ocean & 3816 Tmol & $=\mathrm{P} 8 \times 106$ \\
\hline $\mathrm{C} 4$ & POC deep ocean & $5.6 \times 10^{4} \mathrm{Tmol}$ & $=\mathrm{P} 11 \times 106$ \\
\hline \multicolumn{4}{|l|}{ Fluxes } \\
\hline CF1 & primary production in $\mathrm{W} 1$ & $39.8 \mathrm{Tmol} \mathrm{y}^{-1}$ & {$[1]$} \\
\hline CF2 & POC mineralization in $\mathrm{W} 1$ & $31.5 \mathrm{Tmol} \mathrm{y}^{-1}$ & $=\mathrm{CF} 1-\mathrm{CF} 3-\mathrm{CF} 4$ \\
\hline CF3 & proximal sediment POC burial & 3.6 $\mathrm{Tmoly}^{-1}$ & {$[1]$} \\
\hline CF4 & POC export from $\mathrm{W} 1$ to $\mathrm{W} 2$ & 4.7 $\mathrm{Tmol} \mathrm{y}^{-1}$ & $=\mathrm{PF} 11 \times 106$ \\
\hline CF5 & primary production in $\mathrm{W} 2$ & $560 \mathrm{Tmol} \mathrm{y}^{-1}$ & $=\left(600 \mathrm{Tmol} \mathrm{y}^{-1}[2]\right)-\mathrm{CF} 1$ \\
\hline CF6 & POC mineralization in $\mathrm{W} 2$ & $534 \mathrm{Tmol} \mathrm{y}^{-1}$ & $=(\mathrm{CF} 4+\mathrm{CF} 5)-(\mathrm{CF} 7+\mathrm{CF} 8)$ \\
\hline CF7 & distal sediment POC burial & $2.7 \mathrm{Tmoly}^{-1}$ & $=\mathrm{PF} 16 \times 400[3]$ \\
\hline CF8 & POC export from $\mathrm{W} 2$ to $\mathrm{W} 3$ & $28.0 \mathrm{Tmol} \mathrm{y}^{-1}$ & $5 \%$ of CF5 [4] \\
\hline CF9 & primary production in $\mathrm{W} 3$ & $3600 \mathrm{Tmoly}^{-1}$ & {$[5]$} \\
\hline CF10 & POC mineralization in $\mathrm{W} 3$ & 3131 Tmol y $^{-1}$ & $=\mathrm{CF} 8+\mathrm{CF} 9-\mathrm{CF} 11$ \\
\hline CF11 & POC export from $\mathrm{W} 3$ to $\mathrm{W} 4$ & $497 \mathrm{Tmol} \mathrm{y}^{-1}$ & $=\mathrm{CF} 12 \mathrm{a}+\mathrm{CF} 12 \mathrm{~b}+\mathrm{CF} 13$ \\
\hline CF12a & aerobic $\mathrm{POC}$ respiration in $\mathrm{W} 4$ & $495 \mathrm{Tmol} \mathrm{y}^{-1}$ & $=\mathrm{OF} 2 \times(106 / 138)[6]$ \\
\hline CF12b & anaerobic $\mathrm{POC}$ respiration in $\mathrm{W} 4$ & $0 \mathrm{Tmoly}^{-1}$ & fully oxic deep ocean \\
\hline CF13 & deep sea sediment POC burial & $1.6 \mathrm{Tmol} \mathrm{y}^{-1}$ & $20 \%$ of total POC burial [7] \\
\hline
\end{tabular}

[1] Slomp and Van Cappellen (2004); [2] $600 \mathrm{Tmol} \mathrm{y}^{-1}=$ total primary production of coastal zone, according to Ver et al. (1999); [3] Ingall and Van Cappellen, 1990; [4] Rabouille et al. (2001); [5] Ver et al. (1999); [6] 106/138 = Redfield C/O 2 ratio for aerobic respiration; [7] Berner (1982). 
Table 3. Steady state fluxes of dissolved $\mathrm{O}_{2}$ affecting the oxygenation of deep waters in the modern, pre-anthropogenic ocean. The mass of dissolved $\mathrm{O}_{2}$ in the deep ocean is estimated at $2.2 \times 10^{5} \mathrm{Tmol}$, based on the mean concentration $\left[\mathrm{O}_{2}\right]_{\text {deep }}=170 \mu \mathrm{M}$ (Sarmiento et al., 1988 ) and the size of the deep water reservoir (W4, Table 1). Except for $\mathrm{O}_{2}$ respiration, the fluxes are directly coupled to the water cycle.

\begin{tabular}{llll}
\hline Fluxes & & & \\
\hline OF1 & $\mathrm{O}_{2}$ downwelling (W3 to W4) & $1351 \mathrm{Tmol} \mathrm{y}^{-1}$ & $=\mathrm{WF} 4 \times\left[\mathrm{O}_{2}\right]_{\text {surface }}[1]$ \\
OF2 & aerobic $\mathrm{O}_{2}$ respiration & $644 \mathrm{Tmol} \mathrm{y}^{-1}$ & $=\mathrm{OF} 1-\mathrm{OF} 3-\mathrm{OF} 4$ \\
OF3 & $\mathrm{O}_{2}$ coastal upwelling (W4 to W2) & $64 \mathrm{Tmol} \mathrm{y}^{-1}$ & $=\mathrm{WF} 6 \times\left[\mathrm{O}_{2}\right]_{\text {deep }}$ \\
OF4 & $\mathrm{O}_{2}$ oceanic upwelling (W4 to W3) & $643 \mathrm{Tmol} \mathrm{y}^{-1}$ & $=\mathrm{WF} 5 \times\left[\mathrm{O}_{2}\right]_{\text {deep }}$ \\
\hline
\end{tabular}

[1] $\left[\mathrm{O}_{2}\right]_{\text {surface }}=324 \mu \mathrm{M}$, Hotinski et al. (2000).

authigenic carbonate fluorapatite (CaP) (Fig. 2). Note that the riverine SRP flux includes the contribution of SRP solubilized from particulate reactive $\mathrm{P}$ upon entering the coastal and that the recycling efficiency of $\mathrm{P}$ is higher in the open ocean than in the coastal ocean (Table 4).

\subsection{Water column biogeochemical dynamics}

The standard process descriptions for $\mathrm{C}, \mathrm{O}_{2}$ and $\mathrm{P}$ cycling in the oceans rely on simple first-order rate expressions. That is, for a given chemical constituent, the rate of transformation in a particular ocean reservoir, or the export flux from that reservoir, is linearly related to the mass of the constituent in the reservoir. This approach, which is commonly used in global biogeochemical modeling (Lasaga, 1980; Chameides and Perdue, 1997), limits the number of adjustable model parameters, while still allowing for an assessment of the dynamic response of the system to perturbations (e.g. Mackenzie et al., 1993; Mackenzie, 1998; Ver et al., 1999). Process descriptions relying on deviating rate formulations are discussed explicitly in what follows.

In order to constrain the biogeochemical consequences of changes in ocean circulation, the fluxes describing the transfers of $\mathrm{C}, \mathrm{P}$ and $\mathrm{O}_{2}$ between the ocean reservoirs are directly coupled to the water cycle. Specifically, the flux of a given chemical species from one ocean reservoir to another is expressed as the product of the water flux between the reservoirs and the concentration of the chemical species in the source reservoir. For oceanic and coastal upwelling, however, this approach is only applied to soluble constituents.

It has been postulated that on geological times scales marine biological productivity is primarily limited by the availability of the nutrient phosphorus (Holland, 1984). Many studies have shown that nutrient limitation at a given place and time in the ocean can be complex, with multiple nutrients (e.g. iron, phosphorus, nitrogen) playing a role (Arrigo, 2005). For the ocean as a whole over longer time scales, it is likely that the system will approach the single limiting nutrient end-member situation (Van Cappellen and Ingall, 1996). Phosphorus is the most likely limiting nutrient for global ocean productivity on geological time scales since any short-term nitrogen limitation of primary productivity may be overcome by $\mathrm{N}$-fixation, as elegantly shown in a model study on oceanic N and P cycling by Tyrrell (1999). Hence, in the model, primary production rates in the proximal coastal zone (CF1), the distal coastal zone (CF5) and the surface open ocean (CF9) are assumed to be proportional to the amounts of soluble reactive phosphorus (SRP) in the corresponding reservoirs (P1, P4 and P7). Uptake fluxes of SRP into new biomass (PF2, PF12, PF22) are related to the primary production rates via the Redfield ratio $(\mathrm{C}: \mathrm{P}=106: 1)$.

Removal of POC to sediments of the proximal and distal coastal zones (CF3 and CF7), as well as vertical export of POC to the deeper waters in the open ocean (CF11), are expressed as fractions of the sum of the corresponding primary production rates and, for the distal zone and surface ocean, the input of POC from the adjacent landward reservoir. The fractions are derived from the estimated initial fluxes (Table 2), and are assumed to remain constant in the simulations.

During times when anoxic bottom waters are prevalent, aerobic respiration in the oceans may become limited by the availability of $\mathrm{O}_{2}$. The dependence of the rate of aerobic respiration (in units of $\mathrm{O}_{2}$ equivalents) on both organic matter and $\mathrm{O}_{2}$ availability in the deep ocean is captured by the following rate expression:

$$
\mathrm{AER}=\mathrm{k}_{\mathrm{CF} 12} \times \mathrm{C}_{4} \times\left(\frac{\left[\mathrm{O}_{2}\right]}{\left[\mathrm{O}_{2}\right]+\mathrm{K}_{\mathrm{O}_{2}}}\right) \times\left(\mathrm{O}_{2} / \mathrm{C}\right)_{\text {Redfield }}
$$

where $\left[\mathrm{O}_{2}\right]$ is the average $\mathrm{O}_{2}$ concentration below the mixed surface layer, $\mathrm{K}_{\mathrm{O}_{2}}(=0.1 \mu \mathrm{M})$ corresponds to the $\mathrm{O}_{2}$ concentration below which aerobic respiration effectively shuts down, and $\left(\mathrm{O}_{2} / \mathrm{C}\right)_{\text {Redfield }}(=138: 106)$ is the molar Redfield ratio relating $\mathrm{O}_{2}$ consumption to $\mathrm{C}$ mineralization during aerobic respiration.

When $\mathrm{O}_{2}$ becomes depleted, reduced soluble substances (RS, units of $\mathrm{O}_{2}$ equivalents) may accumulate in the water column. The production of RS below the mixed surface layer, as a result of anaerobic degradation processes is calculated as:

ANAER $=\mathrm{k}_{\mathrm{CF} 12} \times \mathrm{C}_{4} \times\left(1-\frac{\left[\mathrm{O}_{2}\right]}{\left[\mathrm{O}_{2}\right]+\mathrm{K}_{\mathrm{O}_{2}}}\right) \times\left(\mathrm{O}_{2} / \mathrm{C}\right)_{\text {Redfield }}(2)$ 


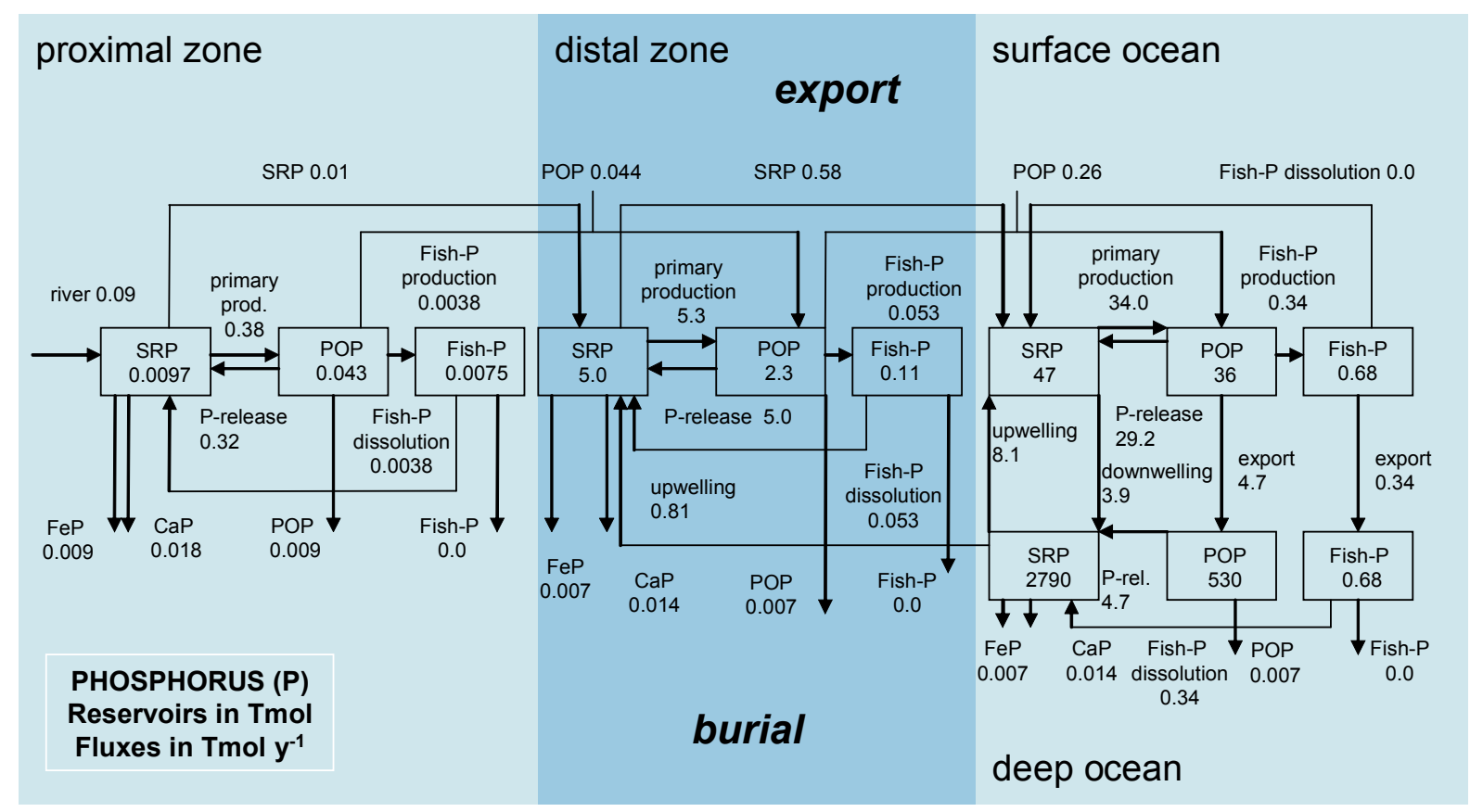

Fig. 2. Modern steady-state oceanic phosphorus (P) cycle. Reservoirs in Tmol; Fluxes in Tmol y ${ }^{-1}$.

The rate equations describing the subsequent fate of RS assume a behavior similar to that expected for free sulfides, which make up the bulk of RS. Thus, the removal of RS as solid phases by burial in sediments is included via a chemical precipitation rate expression:

$\operatorname{RSBUR}=\mathrm{k}_{\mathrm{prec}} \times\left(\frac{[\mathrm{RS}]}{[\mathrm{RS}]_{0}-1}\right) \times \mathrm{W} 4$ when $[\mathrm{RS}] \geq[\mathrm{RS}]_{0}$

where [RS] is the concentration in the deep ocean reservoir, and $\mathrm{k}_{\mathrm{prec}}=1 \times 10^{-3} \mathrm{~mol} \mathrm{~m}^{-3} \mathrm{yr}^{-1}$ (Boudreau, 1997). The threshold concentration [RS $]_{0}$ that must be exceeded for precipitation to take place is set at $0.03 \mathrm{mM}$, which is in accordance with the lower end of the range of dissolved sulfide concentrations observed in the Black Sea (Neretin et al., 2003). The model results for oxygen are insensitive to the actual value imposed for the sulfide threshold concentration, within the range $0.03-0.30 \mathrm{mM}$. As anoxic conditions expand, an increasing fraction of $\mathrm{O}_{2}$ transported by downwelling to the ocean's interior is consumed by the reoxidation of RS, which is described by a bimolecular rate law:

$\mathrm{RSOX}=\mathrm{k}_{\mathrm{ox}} \times\left[\mathrm{O}_{2}\right] \times[\mathrm{RS}] \times \mathrm{W} 4$

with $\mathrm{k}_{\mathrm{ox}}=1 \times 10^{8} \mathrm{~mol} \mathrm{~m}^{-3} \mathrm{yr}^{-1}$ (Boudreau, 1997; Van Cappellen and Wang, 1996).

\subsection{Redox-dependent burial of reactive $\mathrm{P}$ and organic $\mathrm{C}$}

On geological time scales, reactive $\mathrm{P}$ burial in marine sediment plays a key role in controlling ocean biogeochemistry and atmospheric composition (e.g. Holland, 1984; Van Cappellen and Ingall, 1996; Handoh and Lenton, 2003). A dependence of burial of reactive $\mathrm{P}$ associated with ferric iron oxides $(\mathrm{FeP})$ on bottom water oxygenation is generally accepted. Depletion of $\mathrm{O}_{2}$ causes the reductive dissolution of reactive ferric iron oxides, hence releasing the sorbed $\mathrm{P}$ as SRP (e.g. Colman and Holland, 2000). This effect is included in the model via a simple linear correction of the burial flux of $\mathrm{FeP}$ (PF33) for changes in the oxygen content of the deep ocean reservoir:

$\mathrm{PF} 33=(\mathrm{PF} 33)_{\mathrm{t}=0} \times \frac{\left[\mathrm{O}_{2}\right]}{\left[\mathrm{O}_{2}\right]_{\mathrm{t}=0}}$

Since the original study of Ingall et al. (1993), evidence for the redox dependence of the burial of organic P (POP) in marine sediments has been accumulating (Van Cappellen and Ingall, 1996; Ingall and Jahnke, 1997; Slomp et al., 2002; Van Cappellen and Slomp, 2002; Tamburini et al., 2002; Ingall et al., 2005; Fig. 3). In particular, data from eastern Mediterranean sediments clearly illustrate the decreased burial efficiency of POP during times of water column anoxia, while at the same time the preservation of POC increases (Slomp et al., 2002, 2004). Here, we adopt a conservative estimate of the sensitivity of POP burial to water column oxygenation, by assuming that anoxia may reduce the POP burial flux (PF31) by up to $25 \%$. Burial of POP is further assumed to be proportional to the export flux from the surface ocean (PF27):

$\mathrm{PF} 31=f_{\mathrm{PF} 31} \times \mathrm{PF} 27 \times\left(0.75+0.25 \frac{\left[\mathrm{O}_{2}\right]}{\left[\mathrm{O}_{2}\right]_{\mathrm{t}=0}}\right)$ 
Table 4. Steady state reservoir masses and fluxes of the modern, pre-anthropogenic marine phosphorus cycle. Some estimates require reservoir masses and fluxes from Tables 1 and 2 .

\begin{tabular}{|c|c|c|c|}
\hline \multicolumn{4}{|c|}{ Reservoirs } \\
\hline $\mathrm{P} 1$ & SRP proximal coastal zone & $9.7 \times 10^{-3} \mathrm{Tmol}$ & [1] \\
\hline $\mathrm{P} 2$ & POP proximal coastal zone & $4.3 \times 10^{-2} \mathrm{Tmol}$ & $=\mathrm{C} 1 / 106$ \\
\hline P3 & Fish-P proximal coastal zone & $7.5 \times 10^{-3} \mathrm{Tmol}$ & $2 \times$ yearly production $(\mathrm{PF} 3)[2]$ \\
\hline P4 & SRP distal coastal zone & $5.0 \mathrm{Tmol}$ & $=\mathrm{PF} 20 \times(\mathrm{W} 2 / \mathrm{WF} 3)$ \\
\hline P5 & POP distal coastal zone & $2.3 \mathrm{Tmol}$ & $=\mathrm{PF} 21 \times(\mathrm{W} 2 / \mathrm{WF} 3)$ \\
\hline P6 & Fish-P distal coastal zone & $0.11 \mathrm{Tmol}$ & $2 \times$ yearly production (PF13) [2] \\
\hline P7 & SRP surface open ocean & 47 Tmol & $=\mathrm{W} 3 \times[\mathrm{SRP}]_{\text {surface }}[3]$ \\
\hline P8 & POP surface open ocean & 36 Tmol & {$[4]$} \\
\hline P9 & Fish-P surface open ocean & $0.68 \mathrm{Tmol}$ & $2 \times$ yearly production $(\mathrm{PF} 23)[2]$ \\
\hline P10 & SRP deep ocean & 2790 Tmol & $=\mathrm{W} 4 \times[\mathrm{SRP}]_{\mathrm{deep}}[5]$ \\
\hline P11 & POP deep ocean & 530 Tmol & [4] \\
\hline $\mathrm{P} 12$ & Fish-P deep ocean & $0.68 \mathrm{Tmol}$ & $2 \times$ yearly export PF28 [2] \\
\hline \multicolumn{4}{|c|}{ Fluxes } \\
\hline PF1 & $\mathrm{SRP}$ river input to $\mathrm{W} 1$ & $0.09 \mathrm{Tmol} \mathrm{y}^{-1}$ & {$[6]$} \\
\hline PF2 & primary production in $\mathrm{W} 1$ & $0.38 \mathrm{Tmol} \mathrm{y}^{-1}$ & $\mathrm{CF} 1 / 106$ \\
\hline PF3 & Fish production in $\mathrm{W} 1$ & $3.8 \times 10^{-3} \mathrm{Tmol} \mathrm{y}^{-1}$ & $=0.01 \times \mathrm{PF} 2[7]$ \\
\hline PF4 & POP mineralization in $\mathrm{W} 1$ & $0.32 \mathrm{Tmoly}^{-1}$ & $=\mathrm{PF} 2-(\mathrm{PF} 3+\mathrm{PF} 6+\mathrm{PF} 11)$ \\
\hline PF5 & Fish-P dissolution in W1 & $3.8 \times 10^{-3} \mathrm{Tmol} \mathrm{y}^{-1}$ & [8] \\
\hline PF6 & proximal sediment POP burial & $0.009 \mathrm{Tmol} \mathrm{y}^{-1}$ & $=\mathrm{PF} 8[9]$ \\
\hline PF7 & proximal sediment Fish-P burial & $0.0 \mathrm{Tmoly}^{-1}$ & $=\mathrm{PF} 3-\mathrm{PF} 5$ \\
\hline PF8 & proximal sediment FeP burial & $0.009 \mathrm{Tmol} \mathrm{y}^{-1}$ & $=(\mathrm{PF} 1+\mathrm{PF} 4+\mathrm{PF} 5)-(\mathrm{PF} 2+\mathrm{PF} 9+\mathrm{PF} 10)$ \\
\hline PF9 & proximal sediment $\mathrm{CaP}$ burial & $0.018 \mathrm{Tmol} \mathrm{y}^{-1}$ & $=2 \times \mathrm{PF} 8[9]$ \\
\hline PF10 & SRP export from $\mathrm{W} 1$ to $\mathrm{W} 2$ & $0.01 \mathrm{Tmoly}^{-1}$ & [1] \\
\hline PF11 & POP export from $\mathrm{W} 1$ to $\mathrm{W} 2$ & $0.044 \mathrm{Tmol} \mathrm{y}^{-1}$ & $=\mathrm{PF} 1-(\mathrm{PF} 6+\mathrm{PF} 7+\mathrm{PF} 8+\mathrm{PF} 9)-\mathrm{PF} 10$ \\
\hline PF12 & primary production in $\mathrm{W} 2$ & $5.3 \mathrm{Tmoly}^{-1}$ & $=\mathrm{CF} 5 / 106$ \\
\hline PF13 & Fish-P production in W2 & $0.053 \mathrm{Tmol} \mathrm{y}^{-1}$ & $=0.01 \times \mathrm{PF} 12[7]$ \\
\hline PF14 & POP mineralization in $\mathrm{W} 2$ & $5.0 \mathrm{Tmol} \mathrm{y}^{-1}$ & $=(\mathrm{PF} 11+\mathrm{PF} 12)-(\mathrm{PF} 13+\mathrm{PF} 16+\mathrm{PF} 21)$ \\
\hline PF15 & Fish-P dissolution in W2 & $0.05 \mathrm{Tmol} \mathrm{y}^{-1}$ & [8] \\
\hline PF16 & distal sediment POP burial & $0.007 \mathrm{Tmol} \mathrm{y}^{-1}$ & PF18 [9] \\
\hline PF17 & distal sediment Fish-P burial & $0 \mathrm{Tmoly}^{-1}$ & $=\mathrm{PF} 13-\mathrm{PF} 15$ \\
\hline PF18 & distal sediment FeP burial & $0.007 \mathrm{Tmol} \mathrm{y}^{-1}$ & $=(0.7 \times 0.25 \times \mathrm{PF} 1)-(\mathrm{PF} 6+\mathrm{PF} 7+\mathrm{PF} 8+\mathrm{PF} 9)[9,10]$ \\
\hline
\end{tabular}

where $f_{\mathrm{PF} 31}$ is the fraction of the export flux of $\mathrm{P}$ from the surface ocean that is ultimately buried in the modern, fully oxic ocean.

The burial flux of POC in the deep ocean is coupled to that of POP via the organic matter $\mathrm{C}$ to $\mathrm{P}$ burial ratio. In many ancient and modern sediments, organic matter accumulating under anoxic conditions is characterized by molar $\mathrm{C}: \mathrm{P}$ ratios that significantly exceed the Redfield value (Ingall et al., 1993, 2005; Filippelli, 2001; Slomp et al., 2002, 2004). To account for this redox-effect, we use the following equation derived from Van Cappellen and Ingall (1994):

$$
\begin{aligned}
& (\text { POC : POP })_{\text {burial }}= \\
& \frac{(\mathrm{C} / \mathrm{P})_{\text {oxic }} \times(\mathrm{C} / \mathrm{P})_{\text {anoxic }}}{\frac{\left[\mathrm{O}_{2}\right]}{\left[\mathrm{O}_{2}\right]_{\mathrm{t}=0}} \times(\mathrm{C} / \mathrm{P})_{\text {anoxic }}+\left(1-\frac{\left[\mathrm{O}_{2}\right]}{\left[\mathrm{O}_{2}\right]_{\mathrm{t}=0}}\right) \times(\mathrm{C} / \mathrm{P})_{\text {oxic }}}
\end{aligned}
$$

where $(\mathrm{C} / \mathrm{P})_{\text {oxic }}$ and $(\mathrm{C} / \mathrm{P})_{\text {anoxic }}$ are the end-member values for sedimentary organic matter buried under fully oxic and fully anoxic bottom waters, respectively. The value of $(\mathrm{C} / \mathrm{P})_{\text {oxic }}$ is equal to 237 , based on the independently estimated POP and POC burial rates in the deep sea (PF31 and CF13, Tables 2 and 4$)$. The value of $(\mathrm{C} / \mathrm{P})_{\text {anoxic }}$ is fixed at 1100 , the maximum value measured for organic matter in eastern Mediterranean sapropel S1 (Slomp et al., 2004). Consequently, the burial efficiency (BE) of POC, defined as the percentage of the export flux of POC from the surface ocean that is buried in sediment, increases by up to a factor of $\sim 3.7$ when the deep ocean goes from fully oxic to fully anoxic. This is consistent with the observed dependence of organic carbon preservation on oxygen exposure in modern marine depositional environments (Hartnett et al., 1998). Note that the proposed model description allows for 
Table 4. Continued.

\begin{tabular}{|c|c|c|c|}
\hline \multicolumn{4}{|c|}{ Fluxes } \\
\hline PF19 & distal sediment $\mathrm{CaP}$ burial & $0.014 \mathrm{Tmoly}^{-1}$ & $=2 \times \mathrm{PF} 18[9]$ \\
\hline PF20 & SRP export W2 to W3 & $0.58 \mathrm{Tmol} \mathrm{y}^{-1}$ & $=(0.3 \times \mathrm{PF} 1+\mathrm{PF} 36)-\mathrm{PF} 21$ \\
\hline PF21 & POP export from $\mathrm{W} 2$ to $\mathrm{W} 3$ & $0.26 \mathrm{Tmol} \mathrm{y}^{-1}$ & $5 \%$ of PF12 [11] \\
\hline PF22 & primary production in $\mathrm{W} 3$ & $34 \mathrm{Tmol} \mathrm{y}^{-1}$ & $=\mathrm{CF} 9 / 106$ \\
\hline PF23 & Fish-P production in $\mathrm{W} 3$ & $0.34 \mathrm{Tmol} \mathrm{y}^{-1}$ & $=0.01 \times \mathrm{PF} 22[7]$ \\
\hline PF24 & POP mineralization in $\mathrm{W} 3$ & $29.2 \mathrm{Tmol} \mathrm{y}^{-1}$ & (PF21+PF22)-(PF23+PF27) \\
\hline PF25 & Fish-P dissolution in W3 & $0.0 \mathrm{Tmol} \mathrm{y}^{-1}$ & {$[8]$} \\
\hline PF26 & SRP downwelling from $\mathrm{W} 3$ to $\mathrm{W} 4$ & $3.9 \mathrm{Tmol} \mathrm{y}^{-1}$ & $=\mathrm{WF} 4 \times[\mathrm{SRP}]_{\text {surface }}$ \\
\hline PF27 & POP export from $\mathrm{W} 3$ to $\mathrm{W} 4$ & $4.7 \mathrm{Tmol} \mathrm{y}^{-1}$ & $=\mathrm{CF} 11 / 106$ \\
\hline PF28 & Fish-P export from $\mathrm{W} 3$ to $\mathrm{W} 4$ & $0.34 \mathrm{Tmoly}^{-1}$ & $=\mathrm{PF} 23[8]$ \\
\hline PF29 & POP mineralization in $\mathrm{W} 4$ & $4.68 \mathrm{Tmol} \mathrm{y}^{-1}$ & PF27-PF31 \\
\hline PF30 & Fish-P dissolution in W4 & $0.34 \mathrm{Tmol} \mathrm{y}^{-1}$ & PF28 [8] \\
\hline PF31 & deep sediment POP burial & $0.007 \mathrm{Tmol} \mathrm{y}^{-1}$ & PF33 [9] \\
\hline PF32 & deep sediment Fish-P burial & $0.0 \mathrm{Tmol} \mathrm{y}^{-1}$ & PF28-PF30 \\
\hline PF33 & deep sediment FeP burial & $0.007 \mathrm{~T} \mathrm{~mol} \mathrm{y}^{-1}$ & $0.3 \times 0.25 \times \mathrm{PF} 1[9,10]$ \\
\hline PF34 & deep sediment $\mathrm{CaP}$ burial & $0.014 \mathrm{Tmol} \mathrm{y}^{-1}$ & $2 \times$ PF33 [9] \\
\hline PF35 & SRP upwelling W4 to W3 & $8.1 \mathrm{Tmoly}^{-1}$ & $\mathrm{WF} 5 \times[\mathrm{SRP}]_{\text {deep }}[5]$ \\
\hline PF36 & SRP upwelling W4 to W2 & $0.81 \mathrm{Tmoly}^{-1}$ & WF6 $\times[S R P]_{\text {deep }}[5]$ \\
\hline
\end{tabular}

[1] Slomp and Van Cappellen (2004); [2] Haedrich and Merrett (1992); [3] [SRP] $]_{\text {surface }}=0.95 \mu \mathrm{M}$ (range 0.8-1.24 $\mu \mathrm{M}$; Sarmiento et al., 1988; Jahnke, 1992); [4] Ver et al. (1999); [5] [SRP] $]_{\text {deep }}=2.15 \mu \mathrm{M}$ (Sarmiento et al., 1988); [6] Berner and Rao (1994), Howarth et al. (1995); [7] $1 \%$ transfer efficiency between trophic levels (Pauly and Christensen, 1995); [8] (Schenau, 1999); [9] assuming CaP, FeP and POP account for 50\%, 25\% and 25\% of total reactive P burial (Ruttenberg, 1993); [10] assuming 70\% of the total river flux is buried in the proximal and distal coastal zone (compare to 50\% (Föllmi, 1996), 84\% (Howarth et al., 1995) and 92\% (Ruttenberg, 1993); [11] Rabouille et al. (2001).

increased POC burial in the deep sea, even when open ocean primary productivity decreases.

More limited evidence suggests that burial of reactive $\mathrm{P}$ as calcium phosphate phases $(\mathrm{CaP})$ also reflects water column oxygenation. According to selective extraction data from eastern Mediterranean (Slomp et al., 2002, 2004) and Arabian Sea sediments (Schenau and de Lange, 2000, 2001) anoxic bottom waters increase the preservation of phosphatic fish hard parts (Fish-P), but decrease that of authigenic carbonate fluorapatite $(\mathrm{CaP})$. Both simulation results with and without redox- dependent burial of Fish-P and $\mathrm{CaP}$ are discussed below. For Fish-P, the burial flux (PF32) is assumed to be proportional to fish export from the surface ocean (PF28). With the optional redox dependence, the flux then becomes:

$\mathrm{PF} 32=\mathrm{f}_{\mathrm{PF} 32} \times \mathrm{PF} 28 \times\left(1-\frac{\left[\mathrm{O}_{2}\right]}{\left[\mathrm{O}_{2}\right]_{\mathrm{t}=0}}\right)$

with $f_{\mathrm{PF} 32}=0.021$, which implies that only a small fraction of fish debris is preserved in marine sediments, in line with findings for the Arabian Sea (Schenau and de Lange, 2000).

Precipitation of authigenic $\mathrm{CaP}$ at the seafloor represents the main mechanism through which SRP released by the decomposition of organic matter is retained in the sediment (Ruttenberg and Berner, 1993; Filippelli and Delaney, 1996; Slomp et al., 1996; Anderson et al., 2001). Under anoxic bottom waters, this mechanism tends to be less effective, be- cause SRP is regenerated in close proximity to the watersediment interface, hence facilitating its escape to the water column (Slomp et al., 2002). In the redox-dependent $\mathrm{CaP}$ burial option we assume that ocean anoxia may lead to a reduction of up to $50 \%$ of the retention efficiency of SRP by $\mathrm{CaP}$ formation:

$\mathrm{PF} 34=f_{\mathrm{PF} 34} \times \mathrm{PF} 29 \times\left(0.5+0.5 \frac{\left[\mathrm{O}_{2}\right]}{\left[\mathrm{O}_{2}\right]_{\mathrm{t}=0}}\right)$

where $f_{\mathrm{PF} 34}$ corresponds to the fraction of SRP produced by the decomposition of organic matter that is converted into $\mathrm{CaP}$ in today's fully oxic ocean.

\subsection{Equivalent 1-box ocean model}

A new version of the 1-box model of the global marine $C$ and P cycles of Van Cappellen and Ingall (1994) is derived to allow direct comparison of the results of the 1-box model to those of the 4-box model described in Sects. 2.1 to 2.4. The reservoir sizes and steady state fluxes of the original and the new version of the 1-box model are presented in Table 5. The main changes relative to the original model are (1) larger masses of oceanic POC and POP; (2) higher rates of oceanic primary production and $\mathrm{POC}$ burial; (3) a higher continental input and burial flux of reactive $P$ and a modified contribution of the various POP, $\mathrm{CaP}$ and $\mathrm{FeP}$ forms to total reactive $\mathrm{P}$ burial. 
Table 5. Steady state reservoir masses and fluxes of the modern, pre-anthropogenic marine phosphorus and carbon cycles in the original and new 1-box model of Van Cappellen and Ingall (1994). All symbols are as defined in the original model.

\begin{tabular}{|c|c|c|c|c|}
\hline Reservoirs & & Original model & New model & Source of new value \\
\hline M1 & $\begin{array}{l}\text { Total oxidized } \mathrm{C}+ \\
\text { in exogenic cycle terrestrial POC } \\
+ \text { oceanic DOC }\end{array}$ & $65 \times 10^{8} \mathrm{Tmol}$ & $65 \times 10^{8} \mathrm{Tmol}$ & - \\
\hline M2 & $\begin{array}{l}\text { Total exogenic } \mathrm{P} \text { minus } \\
\text { other reservoirs }\end{array}$ & $14 \times 10^{6} \mathrm{Tmol}$ & $14 \times 10^{6} \mathrm{Tmol}$ & - \\
\hline M3 & POC in the oceans & $35 \times 10^{2}$ Tmol & $60 \times 10^{3} \mathrm{Tmol}$ & $\mathrm{C} 1+\mathrm{C} 2+\mathrm{C} 3+\mathrm{C} 4$ \\
\hline M4 & POP in the oceans & 18 Tmol & $5.7 \times 10^{2} \mathrm{Tmol}$ & $\mathrm{P} 2+\mathrm{P} 5+\mathrm{P} 8+\mathrm{P} 11$ \\
\hline M5 & Reactive $\mathrm{P}$ in the oceans & $20 \times 10^{2}$ Tmol & $28 \times 10^{2} \mathrm{Tmol}$ & $\mathrm{P} 1+\mathrm{P} 4+\mathrm{P} 7+\mathrm{P} 10$ \\
\hline M6 & $\begin{array}{l}\text { Marine sedimentary } \\
\text { organic C }\end{array}$ & $13 \times 10^{8} \mathrm{Tmol}$ & $13 \times 10^{8} \mathrm{Tmol}$ & - \\
\hline M7 & $\begin{array}{l}\text { Marine sedimentary } \\
\text { organic } \mathrm{P}\end{array}$ & $52 \times 10^{5} \mathrm{Tmol}$ & $37 \times 10^{5} \mathrm{Tmol}$ & $\mathrm{M} 6 /\left(\mathrm{F}_{36} / \mathrm{F}_{47}\right)$ \\
\hline M8 & authigenic + biogenic $\mathrm{CaP}$ & $52 \times 10^{5} \mathrm{Tmol}$ & $74 \times 10^{5} \mathrm{Tmol}$ & $\mathrm{M} 8=2 \times \mathrm{M} 7$ \\
\hline M9 & $\mathrm{P}$ bound to Fe (hydr)oxides & $22 \times 10^{5} \mathrm{Tmol}$ & $37 \times 10^{5} \mathrm{Tmol}$ & $\mathrm{M} 9=\mathrm{M} 7$ \\
\hline \multicolumn{5}{|l|}{ Fluxes } \\
\hline $\mathrm{F}_{13}$ & $\begin{array}{l}\text { Net oceanic primary } \\
\text { production }\end{array}$ & $25 \times 10^{2} \mathrm{Tmol} \mathrm{y}^{-1}$ & $42 \times 10^{2} \mathrm{Tmol} \mathrm{y}^{-1}$ & $\mathrm{CF} 1+\mathrm{CF} 5+\mathrm{CF} 9$ \\
\hline $\mathrm{F}_{54}$ & $\begin{array}{l}\text { Biological fixation of } \\
\text { reactive } \mathrm{P}\end{array}$ & $\mathrm{F}_{13} / 106$ & $\mathrm{~F}_{13} / 106$ & - \\
\hline $\mathrm{F}_{36}$ & $\begin{array}{l}\text { Burial of POC in marine } \\
\text { sediments }\end{array}$ & $3.75 \mathrm{Tmoly}^{-1}$ & 7.9 $\mathrm{Tmoly}^{-1}$ & $\mathrm{CF} 3+\mathrm{CF} 7+\mathrm{CF} 13$ \\
\hline $\mathrm{F}_{31}$ & Mineralization of POC & $\mathrm{F}_{13}-\mathrm{F}_{36}$ & $\mathrm{~F}_{13}-\mathrm{F}_{36}$ & - \\
\hline $\mathrm{F}_{47}$ & $\begin{array}{l}\text { Burial of POP in oceanic } \\
\text { sediments }\end{array}$ & $\mathrm{F}_{36} / 250$ & $\mathrm{~F}_{36} / 350$ & $25 \%$ of total P burial as POP \\
\hline $\mathrm{F}_{45}$ & Recycling of POP in oceans & $\mathrm{F}_{54}-\mathrm{F}_{47}$ & $\mathrm{~F}_{54}-\mathrm{F}_{47}$ & \\
\hline $\mathrm{F}_{58}$ & $\begin{array}{l}\text { Burial of } \mathrm{CaP} \text { in marine } \\
\text { sediments }\end{array}$ & $0.015 \mathrm{Tmol} \mathrm{y}^{-1}$ & $0.045 \mathrm{Tmol} \mathrm{y}^{-1}$ & $50 \%$ of total $\mathrm{P}$ burial as $\mathrm{CaP}$ \\
\hline $\mathrm{F}_{59}$ & $\begin{array}{l}\text { Burial of } \mathrm{FeP} \text { in marine } \\
\text { sediments }\end{array}$ & $0.006 \mathrm{Tmol} \mathrm{y}^{-1}$ & $0.023 \mathrm{Tmol} \mathrm{y}^{-1}$ & $25 \%$ of total $\mathrm{P}$ burial as $\mathrm{FeP}$ \\
\hline $\mathrm{F}_{25}$ & $\begin{array}{l}\text { Reactive P flux from } \\
\text { continents to oceans }\end{array}$ & $0.036 \mathrm{Tmol} \mathrm{y}^{-1}$ & $0.09 \mathrm{Tmol} \mathrm{y}^{-1}$ & PF1 \\
\hline $\mathrm{F}_{61}$ & $\begin{array}{l}\text { Uplift and exposure of } \\
\text { marine sedimentary POC }\end{array}$ & $\mathrm{F}_{36}$ & $\mathrm{~F}_{36}$ & - \\
\hline $\mathrm{F}_{72}, \mathrm{~F}_{82}, \mathrm{~F}_{92}$ & $\begin{array}{l}\text { Uplift and exposure of } \\
\text { marine sedimentary POP }\end{array}$ & $\mathrm{F}_{47}, \mathrm{~F}_{58}, \mathrm{~F}_{59}$ & $\mathrm{~F}_{47}, \mathrm{~F}_{58}, \mathrm{~F}_{59}$ & - \\
\hline
\end{tabular}

All rate laws used in the new 1-box model are taken from Van Cappellen and Ingall (1994), except for those describing POC and POP burial fluxes. These are assumed to be redox-dependent according to Eqs. (6) and (7), except that the degree of anoxicity of the oceans (DOA; ranging from 0 1 ) is used rather than the $\mathrm{O}_{2}$ concentration of the deep ocean water. DOA is defined by Van Cappellen and Ingall (1994) as:

$\mathrm{DOA}=1-\mathrm{k}_{\mathrm{OA}} \times \frac{\mathrm{v}_{\text {mix }}}{\mathrm{F}_{13}}$

where $\mathrm{k}_{\mathrm{OA}}$ is an apparent constant which is proportional to the average dissolved oxygen concentration of downwelling surface waters, $v_{\text {mix }}\left(\mathrm{my}^{-1}\right)$ is the linear vertical mixing rate of the ocean (Van Cappellen and Ingall, 1994) and $F_{13}$ is net oceanic primary productivity (Table 5). In Eqs. (6) and (7), $\left[\mathrm{O}_{2}\right] /\left[\mathrm{O}_{2}\right]_{t=0}$ is then replaced by (1-DOA). A nondimensional mixing parameter $f_{\text {mix }}^{\text {oce }}$ was derived by normalizing $\mathrm{v}_{\text {mix }}$ to the present-day mixing rate in the oceans $(3 \mathrm{~m}$ $\mathrm{y}^{-1}$ ). This allows direct comparison to the non-dimensional mixing parameters of the 4-box model (Sect. 2.1)

\subsection{Numerical solution}

The ordinary differential equations describing mass conservation in the models are solved using the MATLAB software 


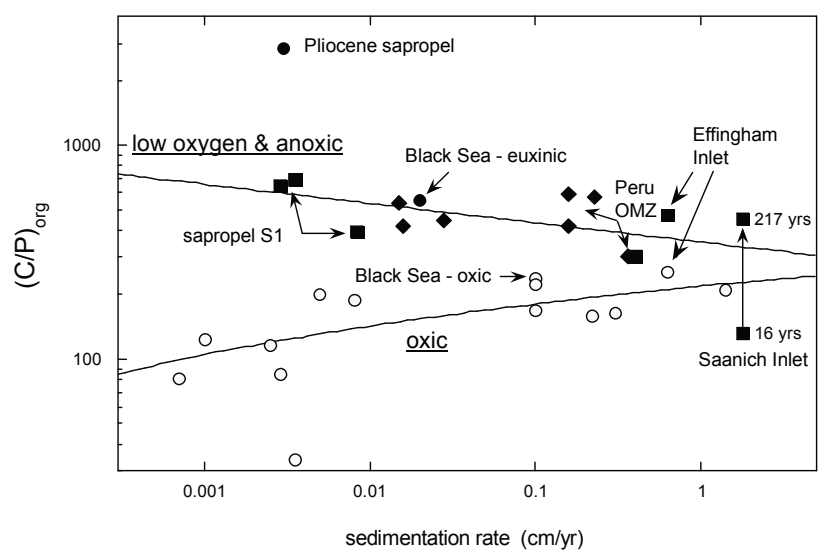

Fig. 3. Compilation of average molar carbon to phosphorus in buried sedimentary organic matter $\left(\mathrm{C} / \mathrm{P}_{\text {org }}=\mathrm{POC} / \mathrm{POP}\right)$ for various modern and recent marine depositional environments showing the dependence on the redox state of the bottom waters. Oxic: open circles; Low oxygen: closed diamonds; Anoxic: closed squares; Euxinic: closed circles. $\mathrm{OMZ}=\mathrm{Oxygen}$ Minimum Zone. The two points for Saanich Inlet correspond to two depth intervals from the same core. Sources: Carman et al. (1996); Filippelli (2001); Hammond et al. (1999); Ingall and Van Cappellen (1990); Ingall et al. (2005); Schenau (1999); Schenau et al. (2000); Slomp et al. (1996, 1998, 2002, 2004); Van Cappellen and Ingall (1997).

(version 6.5). In the 4-box model, small round-off errors in the rate constants and proportionality constants cause slight shifts (generally $<0.4 \%$ ) of the actual steady-state masses and fluxes from the values presented in Tables 1-4. The model is therefore run for several kyrs prior to imposing a perturbation, in order to ensure that the initial state truly represents steady state conditions. A typical simulation run takes about $10 \mathrm{~s}$ on a PC. The model is available from the first author upon request

\section{Results and discussion}

The main objective of the model simulations is to determine how marine primary production and sedimentary burial of $\mathrm{C}$ and $\mathrm{P}$ respond when oceanic circulation decreases relative to present-day conditions. A slowing down of thermohaline circulation is frequently invoked to explain the appearance of global scale ocean anoxia in the geological past (e.g. Schlanger and Jenkyns, 1976; Erbacher et al., 2001; for a discussion of other possible causes see Hotinski et al., 2000), and is also considered to be a potential future consequence of anthropogenically-driven global warming (Broecker, 1997; IPCC, 2001). In order to highlight the roles of the continental margins and the exchanges of phosphorus between the coastal and open oceans, the response of the 4-box ocean model is compared to that of the new 1-box model (Sect. 2.5). Because some of the process descriptions and initial conditions deviate from those in the original 1-box ocean model of Van Cappellen and Ingall (1994), we first examine to what extent the steady state behaviours of the new and old 1-box models differ from one another.

\subsection{One-box ocean models}

As in the original 1-box ocean model of Van Cappellen and Ingall $(1994,1996)$, we assume that the carbon to phosphorus ratio of organic matter being buried in marine sediments reflects the redox conditions of the overlying water column (Eq. 7). The redox-dependence of buried (C/P) org is illustrated in Fig. 3, where existing data for modern and geologically recent marine sediments are compiled. The differentiation of POC and POP burial between oxic and anoxic depositional environments is most pronounced at low sedimentation rates typical of the deep-sea, implying a dependence of $(\mathrm{C} / \mathrm{P})_{\text {org }}$ on the duration and extent of the early diagenetic processing of organic matter. This is consistent with $(\mathrm{C} / \mathrm{P})_{\text {org }}$ ratios measured by Filippelli (2001) on sediment from a core collected in the anoxic part of Saanich Inlet (Fig. 3). The $(\mathrm{C} / \mathrm{P})_{\text {org }}$ value is close to the Redfield ratio in the recently deposited core-top material, but increases significantly with depth in the core (Fig. 3).

In the original 1-box model for the coupled biogeochemical cycles of $\mathrm{C}, \mathrm{P}$ and $\mathrm{O}_{2}$, the higher $(\mathrm{C} / \mathrm{P})_{\text {org }}$ ratios buried under anoxic conditions were ascribed to a decreased burial efficiency of organic P in marine sediments. The burial efficiency of POC was assumed independent of water column oxygenation. In this manner, the then still controversial issue of whether or not POC preservation in sediments is higher under anoxic bottom waters was avoided (Canfield, 1994). As a consequence, in the original model, changes in the POC burial flux were due only to variations in primary production. Since then, the accumulating evidence has clearly established that POC preservation depends on the availability of oxygen (Hartnett et al., 1998; Hedges et al., 1999; Meile and Van Cappellen, 2005). Therefore, in the new model, the increase in $(\mathrm{C} / \mathrm{P})_{\text {org }}$ under anoxia reflects the combined decrease in POP burial efficiency and increased burial efficiency of POC.

The steady state response of the original and new onereservoir ocean models to decreasing ocean circulation are compared in Fig. 4. Note that some of the differences are due to differences in the initial estimates of primary production and burial fluxes for the modern ocean in the two models. It is therefore more meaningful to look at the relative trends in the output of the models. Some common features can be observed. In particular, decreased oceanic circulation, and thus decreased deep water ventilation, is accompanied by increased anoxia and an accumulation of SRP in the oceans' water column. The greater availability of SRP overcompensates the slower vertical water exchange rates and leads to higher oceanic primary productivity.

Thus, both models predict enhanced benthic regeneration of SRP under anoxic bottom waters, a feature which has been confirmed in modern marine environments by benthic 

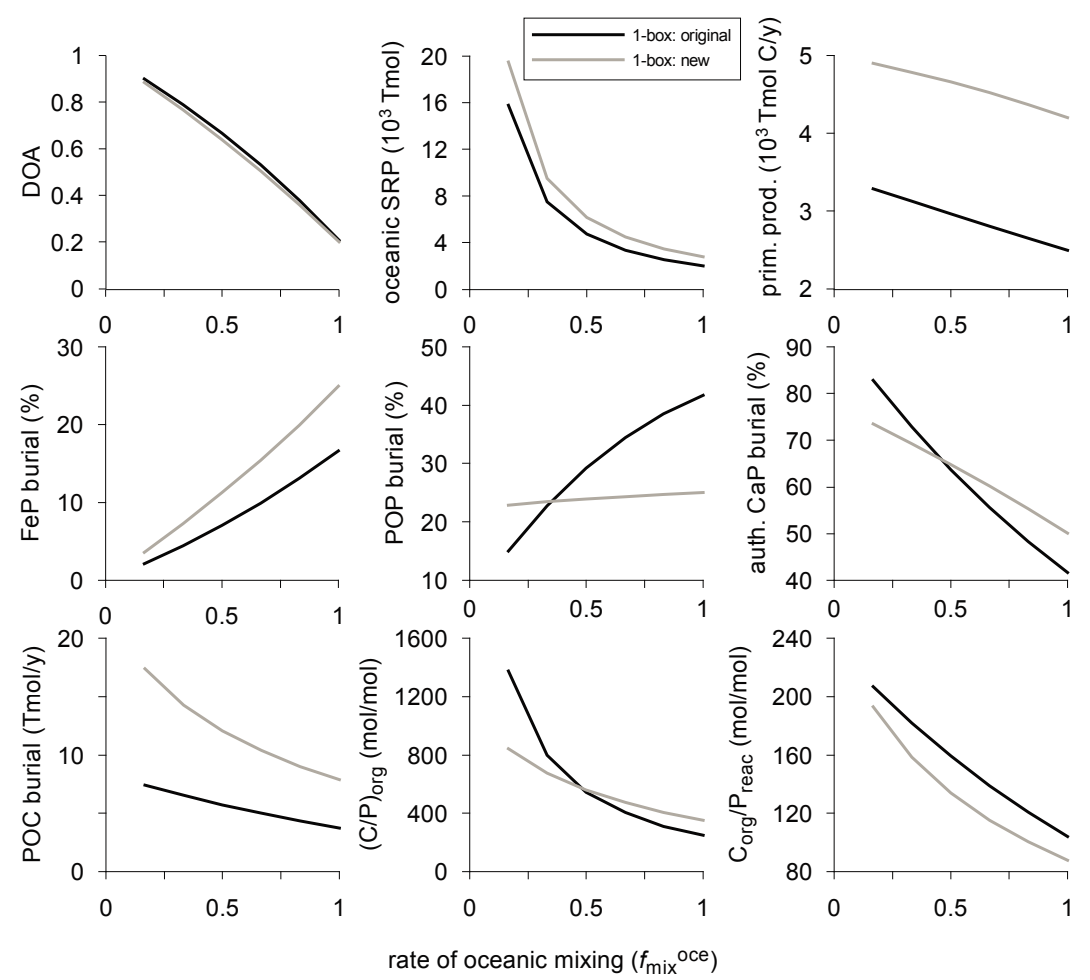

Fig. 4. Steady state response of the degree of anoxicity of the ocean (DOA) and the oceanic cycles of $\mathrm{P}$ and $\mathrm{C}$ to reduced oceanic circulation as calculated with the original 1-box model of Van Cappellen and Ingall (1994) (black lines) and the new 1-box model described in Sect. 2.5 (grey lines). The non-dimensional mixing parameter $f_{\mathrm{mix}}^{\text {oce }}$ for the modern ocean is $1 . \mathrm{P}_{\text {reac }}$ stands for total reactive $\mathrm{P}$.
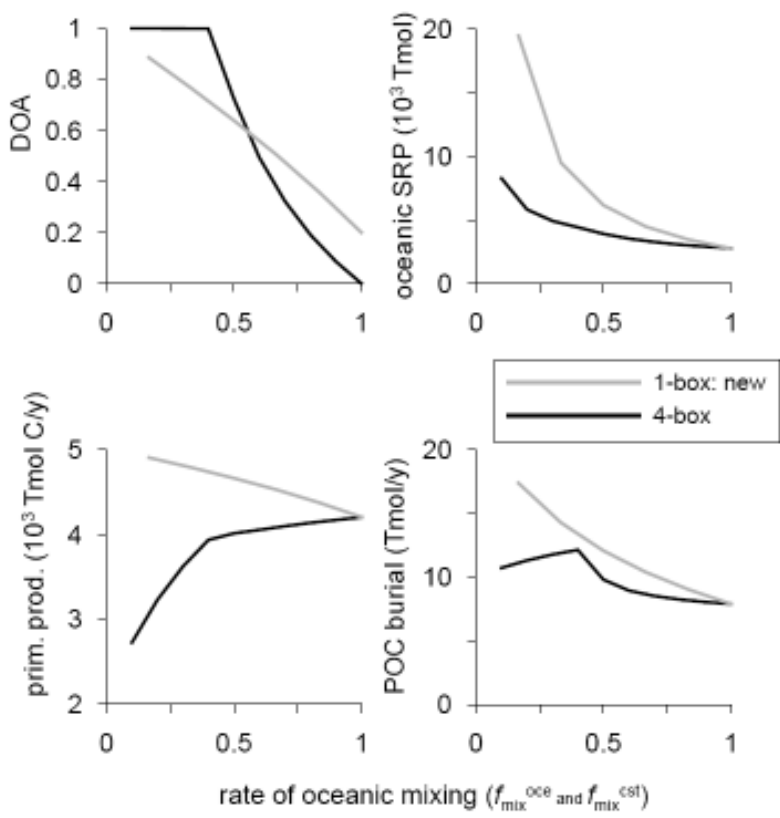

Fig. 5. Steady state response of DOA, the reservoir of oceanic SRP $\left(10^{3}\right.$ Tmol P), primary productivity $\left(10^{3} \mathrm{TmolC}^{-1}\right)$ and POC burial ( $\mathrm{Tmol} \mathrm{Cy}^{-1}$ ) to reduced oceanic circulation for the new 1box model (grey lines) and the 4-box model (black lines). Note that $f_{\text {mix }}^{\text {cst }}$ and $f_{\text {mix }}^{\text {oce }}$ change simultaneously in the 4-box model. DOA in the 4-box model is calculated directly from the deep ocean $\mathrm{O}_{2}$ concentrations as $\mathrm{DOA}=1-\left[\mathrm{O}_{2}\right] /\left[\mathrm{O}_{2}\right]_{t=0}$ chamber deployments (Ingall and Jahnke, 1997). The more efficient recycling of SRP is due to the lower retention of reactive $\mathrm{P}$ by iron oxides and organic matter in sediments. That is, with decelerating ocean circulation, the contribution of authigenic $\mathrm{CaP}$ to total reactive $\mathrm{P}$ burial increases, relative to that of POP and FeP (sink-switching). The main difference between the model outputs is that, in the new 1-box model, the decrease in POP burial with decreasing ocean ventilation is less pronounced, as enhanced preservation of POC now in part explains the drop in $(\mathrm{C} / \mathrm{P})_{\text {org }}$. In other words, in the new model, enhanced POC preservation causes less sinkswitching from $\mathrm{POP}$ to authigenic $\mathrm{CaP}$.

\subsection{One-versus four-box ocean models}

The 1- and 4-box models show a a similar increase in the degree of anoxicity (DOA) but a very different response of the marine $\mathrm{C}$ and $\mathrm{P}$ cycles to reduced oceanic circulation (Fig. 5). In these simulations, both open ocean and coastal upwelling are reduced in the 4-box model, by decreasing the mixing parameters $f_{\text {mix }}^{\text {cst }}$ and $f_{\text {mix }}^{\text {oce }}$ simultaneously. Although there is still a build-up of SRP in the (deep) oceanic waters in the 4-box model, it is much less pronounced than in the 1-box model. The most dramatic effect of explicitly including the coastal ocean, however, is the reversed trend in total marine primary productivity: as ocean circulation slows down, primary production actually decreases. This indicates 


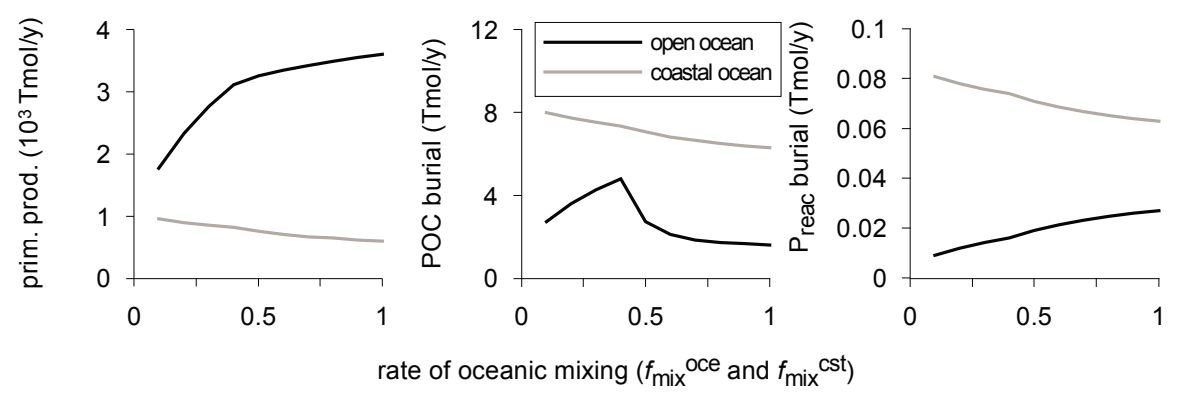

Fig. 6. Comparison of the contribution of the coastal (grey lines) and open ocean (black lines) to primary productivity $\left(10^{3} \mathrm{Tmol} \mathrm{C}^{-1}\right)$ and burial of POC and reactive $\mathrm{P}\left(\mathrm{Tmol}^{-1}\right)$ upon decreased circulation for the 4-box model.

a fundamentally different functioning of a model ocean that accounts for reactive $\mathrm{P}$ exchanges between the continental margins and the open ocean reservoirs.

The decrease in total marine primary production when circulation slows down is mainly due to a drop in open ocean productivity (Fig. 6). In contrast, coastal ocean primary production is predicted to increase, due to upwelling of SRPenriched deep waters onto the shelves and reduced export of SRP and POP to the open ocean. The slowing down of oceanic circulation also shifts more burial of POC and reactive $\mathrm{P}$ to the coastal ocean (Fig. 5 and 6). Because reactive $\mathrm{P}$ is being transferred to and retained in the coastal zone, the SRP build-up in the deep waters of the 4-box model is unable to offset the decreasing rate of oceanic upwelling. Less SRP makes it to the open ocean surface waters, resulting in lower open ocean primary productivity.

Nonetheless, despite decreased open ocean primary productivity, POC burial in the deep-sea increases until oceanic and coastal mixing intensities reach $40 \%$ of their present-day values. In the coastal ocean increased POC burial is the result of elevated primary productivity, whereas in the deep ocean it is a preservation effect due to anoxia. Thus, coeval deposition of organic C-rich sediments in coastal and deep sea sediments during periods of ocean anoxia does not necessarily imply a similar mechanism of formation. For the given model structure and parameter values, the open ocean below the mixed surface layer becomes fully anoxic when $f_{\text {mix }}^{\text {cst }}$ and $f_{\text {mix }}^{\text {oce }}$ drop to 0.4. Thus, no further redox-dependent build-up of the deep water SRP concentration occurs when lowering $f_{\text {mix }}^{\text {cst }}$ and $f_{\text {mix }}^{\text {oce }}$ below 0.4. Continued slowing down of the rate of oceanic upwelling is then accompanied by a stronger decrease in open ocean primary productivity.

In both the open and coastal ocean compartments, authigenic $\mathrm{CaP}$ is the major sink of reactive $\mathrm{P}$ (Fig. 7). The relative importance of this sink in the deep sea increases when ocean circulation slows down, because organic and iron(III)-bound $P$ become less efficient sinks when bottom water oxygenation decreases. When explicitly assuming that the burial fluxes of authigenic CaP and Fish-P are redox-dependent (Sect. 2.4), fish debris become quantitatively as important as authigenic

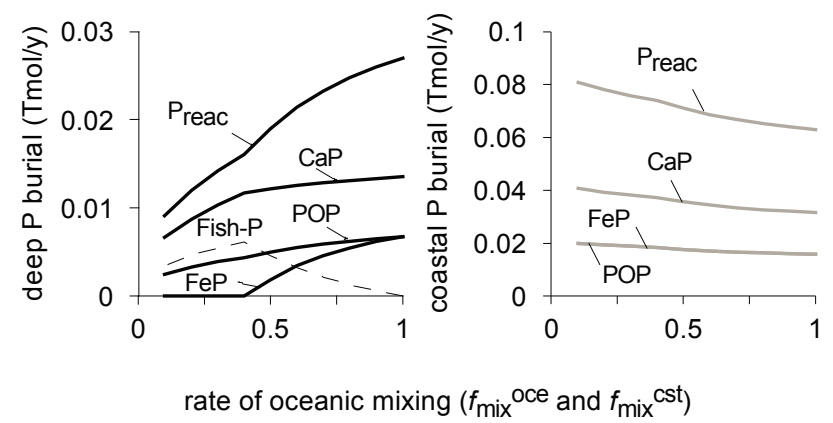

Fig. 7. Phosphorus speciation in deep sea and coastal sediments upon decreased circulation for the 4-box model. The dotted line indicates the burial flux of fish debris (Fish-P) when both phosphatic fish debris and authigenic calcium phosphate $(\mathrm{CaP})$ burial are assumed to be redox-dependent.

$\mathrm{CaP}$ when $f_{\text {mix }}^{\text {cst }}$ and $f_{\text {mix }}^{\text {oce }}$ drop below 0.5 . Thus, in a largely anoxic ocean, burial of fish hard parts may become a major removal pathway of reactive $\mathrm{P}$, even though the burial flux represents only a minor fraction $(\approx 2 \%)$ of fish debris settling out of the ocean's surface layer. The importance of Fish-P as a reactive $\mathrm{P}$ sink under anoxia is supported by selective extraction data for Mediterranean sapropels (Slomp et al., 2002) and recent sediments of the Arabian Sea (Schenau and de Lange, 2001). The exact mechanism causing the redox-dependent preservation of phosphatic fish hard parts is presently unknown, however.

These results suggest that, in the geological past when fish in the ocean were less common or not yet evolved, reduced oceanic circulation would lead to higher steady state concentrations of soluble $\mathrm{P}$ in the deep ocean than today. Thus, the oceans may have been more prone to enter the positive feedback loop of increased anoxia and $\mathrm{P}$ regeneration driving enhanced primary productivity and further increased anoxia (Van Cappellen and Ingall, 1996). 


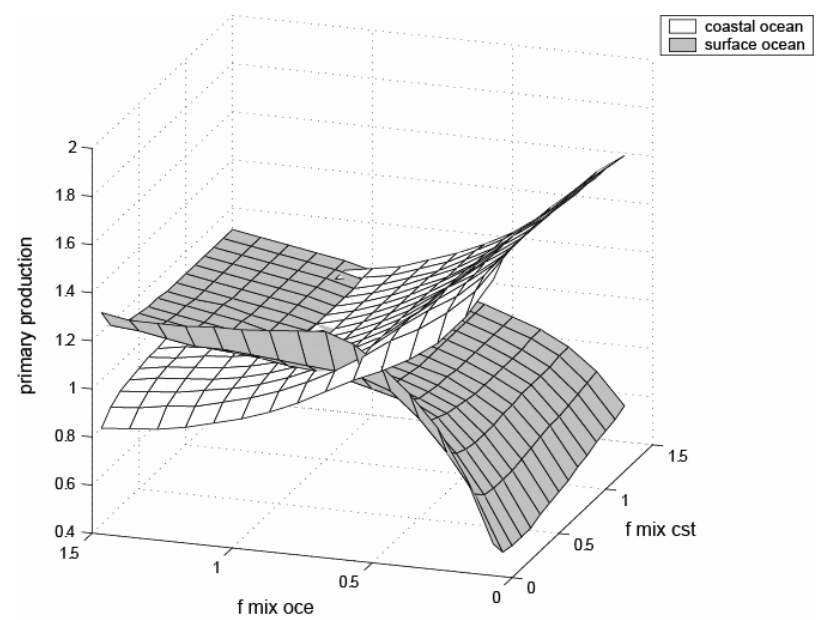

Fig. 8. Steady state response of coastal ocean and surface ocean primary productivity (on a relative scale, with 1 being the value assumed for the modern, pre-anthropogenic ocean) to independent changes in $f_{\text {mix }}^{\text {cst }}$ and $f_{\text {mix }}^{\text {oce }}$.

\subsection{Coastal versus oceanic upwelling}

Thus far in the simulations we have assumed that the ratio

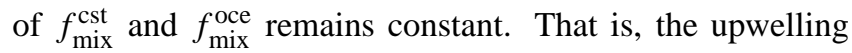
water fluxes from the deep ocean to the coastal ocean and the surface open ocean are strictly coupled to one another. Coastal and oceanic upwelling can vary independently, however (e.g. Rahmstorf, 2002). The possible consequences of decoupled coastal and oceanic upwelling for primary production in the coastal and surface ocean are analyzed in Fig. 8. The model predicts that changes in open ocean vertical circulation $\left(f_{\mathrm{mix}}^{\text {oce }}\right)$ largely determine primary production in both the coastal and surface ocean.

According to Fig. 8, coastal ocean primary productivity is enhanced when oceanic upwelling is decreased, regardless of the actual rate of coastal upwelling. This is because the SRP concentration of waters exported from the distal coastal zone does not increase proportionally to that of the deep ocean water reservoir upon decreased oceanic circulation. The net effect of decreasing vertical mixing in the ocean is therefore increased SRP retention. On geological time scales, decreased circulation in the open ocean should thus lead to increased primary productivity and reactive $\mathrm{P}$ burial on the shelves. Increased vertical circulation, in contrast, reduces the transfer of SRP to the coastal ocean and shifts primary production back to the open surface ocean.

\subsection{Off-shelf transport of particulate matter}

Transfer of particulate matter across the shelf break is driven by local waves and currents and may be decoupled from large-scale changes in water circulation. This particularly holds for particles that are not continuously in suspension and that are transported along the seafloor. These particles may be transported off-slope into the deep sea rather than being transferred to the surface ocean (e.g. Walsh, 1991). Chen et al. (2003) estimate that roughly $50 \%$ of the total POC exported to the open ocean may directly enter the deep sea in this manner. We therefore also assessed the effects of changes in circulation on primary productivity and burial of reactive $\mathrm{P}$ and POC when (1) 50\% of the POC and POP transfer from shelves enters the deep ocean and (2) this off shelf particulate transfer is independent of water circulation.

Processes in the coastal ocean are barely affected by the modified transfer of particulate organic matter to the open ocean (Fig. 9). For the coastal zone, it matters little whether organic matter is buried locally, or exported to the open ocean. However, the change in off-shelf particulate transport regime has a significant impact on the biogeochemical functioning of the open ocean. In particular, the sustained supply of degradable POC and POP from the shelves, as global water circulation slows down, results in higher surface ocean productivity and higher burial of $\mathrm{POC}$ and reactive $\mathrm{P}$ in deepsea sediments, relative to the standard run (Fig. 9). These results highlight the need for more quantitative and processbased knowledge of the transfer of particulate organic matter from the coastal to the open ocean and the effects on marine biogeochemical cycles.

\subsection{Redox-dependent P burial}

The more complete representation of ocean circulation and exchanges between the coastal and open ocean in the 4-box ocean model results in a more complex response of marine productivity to circulation-induced changes in $\mathrm{P}$ recycling than in the 1-box model (Fig. 5 and 6). The role of redoxdependent $\mathrm{P}$ and $\mathrm{C}$ burial is illustrated by running the 4-box model for a scenario where reactive $\mathrm{P}$ and POC burial in the deep ocean are assumed independent of redox conditions (no redox; Fig. 9). The results show that, in contrast to the 1box ocean model, enhanced SRP regeneration under anoxic conditions in the deep ocean has only a fairly limited effect on surface ocean primary productivity (compare the standard and no redox runs in Fig. 9).

So far, we have assumed that coastal ocean waters remain fully oxygenated, even when global ocean circulation becomes sluggish. High coastal productivity and limited exchange with the open ocean could have led to large-scale shallow water anoxia during the geological past, however. To account for variable bottom water oxygenation along the continental margins, the degree of anoxicity of the distal coastal ocean reservoir, $\mathrm{DOA}_{\mathrm{cst}}$, is introduced. It is defined using Eq. (10), by replacing $\mathrm{v}_{\text {mix }}$ by $f_{\text {mix }}^{\text {cst }}$ and $\mathrm{F}_{13}$ by the primary productivity of the distal ocean, CF5. The value of $\mathrm{k}_{O A}$ is then obtained from the initial value of CF5 (Table 2), with $f_{\text {mix }}^{\text {cst }}=1$. With this formulation, DOA cst $_{\text {ct }}$ equals 0.71 when $f_{\text {mix }}^{\text {cst }}$ and $f_{\text {mix }}^{\text {oce }}$ are both equal to 0.5 , i.e., a large fraction of 

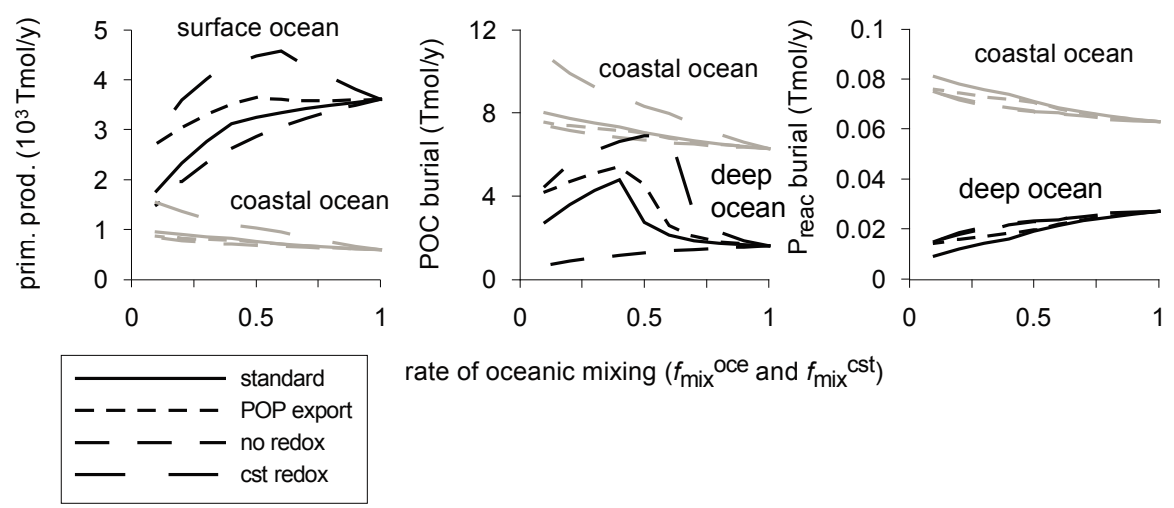

Fig. 9. Steady state response of surface and coastal ocean primary productivity (in $10^{3} \mathrm{Tmol}^{-1}$ ), and burial of POC and reactive $\mathrm{P}$ (in Tmol $\mathrm{y}^{-1}$ ) to decreased circulation in 4 scenarios: (1) standard (drawn line); (2) 50\% of POP and POC transfer from shelves to open ocean independent of circulation (POP export; short dash); (3) no redox-dependent reactive P and POC burial in the deep ocean (no redox; medium dash); (4) redox-dependent reactive P and POC burial in the distal ocean (cst redox; long dash).

the coastal ocean turns anoxic as water exchange with the open ocean is substantially reduced.

When both the oxygenation of the deep sea and the coastal ocean are allowed to vary with changing oceanic circulation, reactive $\mathrm{P}$ is much more efficiently recycled within the oceanic system. As a consequence, coastal and open ocean primary production rates are significantly higher than in the standard run (Fig. 9). In fact, for $f_{\text {mix }}^{\text {cst }}$ and $f_{\text {mix }}^{\text {oce }}$ values between 1 and 0.5 , total ocean primary productivity actually increases with decreasing circulation rates, as observed in the 1-box model simulations (Fig. 4). Slower ocean circulation still shifts burial of reactive $\mathrm{P}$ to the coastal zone at the expense of the deep ocean, but less than in the standard run. Given the high degree of wind mixing typical of presentday shelves (e.g. Rabouille et al., 2001), large-scale shallow water anoxia in the past most likely required a different configuration of the global coastal ocean, for example, one dominated by extensive, semi-enclosed epicontinental seas.

\subsection{Transient response to decreased oceanic circulation}

All previous results correspond to steady state conditions following an imposed change in oceanic circulation. Given the residence time of reactive $\mathrm{P}$ of $39 \mathrm{ky}$ assumed in the model, the coupled global marine $\mathrm{C}$ and $\mathrm{P}$ cycles are expected to respond on time scales of at least tens of thousands of years. The transient response of the 4-box ocean model is illustrated in Fig. 10 for an instantaneous 50\% decline in oceanic circulation rates.

The drop in circulation immediately affects the transfer fluxes of solute species in the ocean system and, hence, causes instantaneous changes of the $\mathrm{C}$ and $\mathrm{P}$ cycles in the coastal and open ocean compartments, followed by a slow relaxation toward the new steady state conditions (Fig. 10). For instance, open ocean primary production initially drops by $30 \%$ and then gradually approaches a new steady state value about $10 \%$ lower than the initial rate. The recovery in primary production takes on the order of 200 to $300 \mathrm{ky}$, and parallels that of the build-up in the deep-water SRP concentration. In a similar fashion, POC burial in the open ocean initially decreases, because of lower primary production, but then rises again due to the lowering of oxygen availability in the deep ocean, which enhances POC preservation.

For the entire duration of the simulation, the decrease in oceanic circulation predicts a lower surface ocean primary production. This seems in contradiction with the proposed enhanced primary production during oceanic anoxic events (OAEs) in the Cretaceous (e.g. Kuypers et al., 2002). The contradiction can be resolved, however, if the bottom waters over large parts of the continental margins became anoxic (Sect. 3.5), as has been suggested for the northwest African shelf during OAE2 (Kolonic et al., 2005), or if the supply of reactive $\mathrm{P}$ from the continents was higher during OAEs (e.g. Erbacher et al., 1996). As shown by Fig. 10, a $20 \%$ increase in reactive $\mathrm{P}$ supply from the continents, for example due to coastal erosion linked to sealevel rise (Erbacher et al., 1996; Bjerrum et al., 2006), would be sufficient to increase oceanic primary productivity and cause a major enhancement of POC burial in marine sediments during periods of reduced circulation.

The transient simulation results also illustrate that the circulation-induced redistribution of reactive $\mathrm{P}$ burial between the open and coastal oceans is quite sensitive to the redox-dependent recycling of reactive $\mathrm{P}$ (compare the no redox and standard runs in Fig. 10). When redox-dependent burial of POP and FeP is included in the model calculations, significantly more reactive $\mathrm{P}$, mainly as authigenic $\mathrm{CaP}$, is buried in coastal sediments, at the expense of deep-sea sediments. The transfer of reactive $\mathrm{P}$ accumulation from the open ocean to the continental margins may help explain the massive phosphorite deposits, which often coincided with 

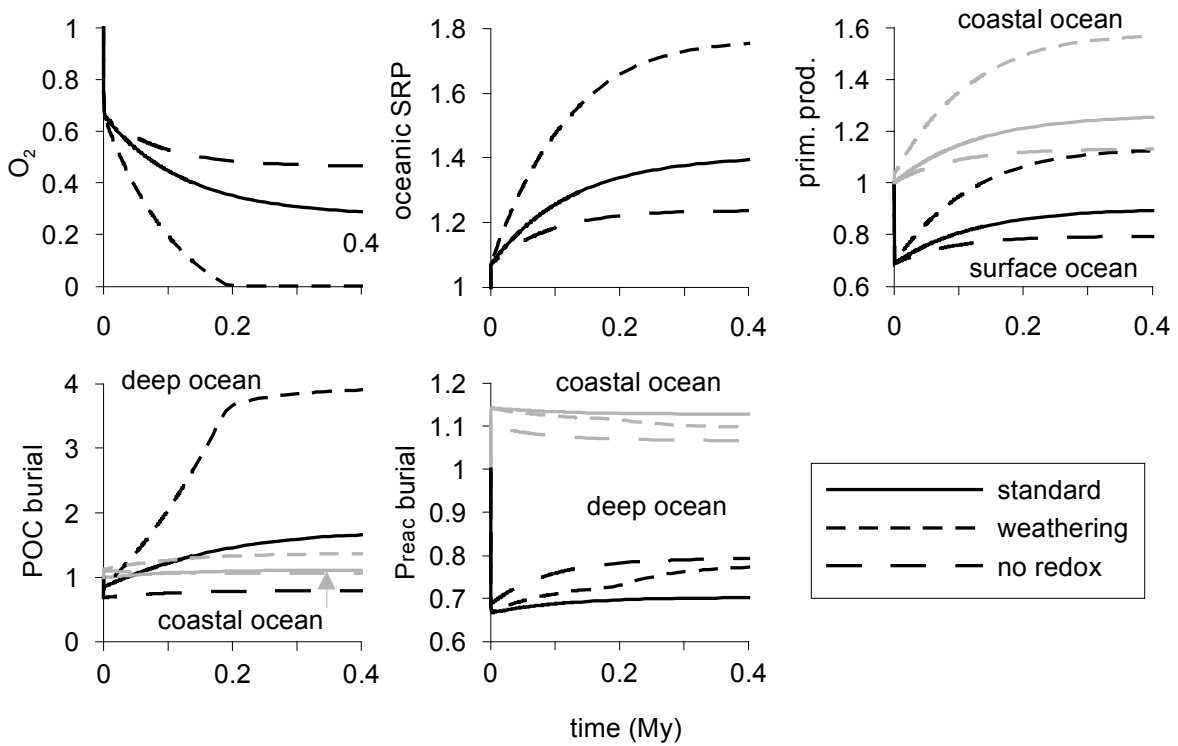

Fig. 10. Transient response of deep ocean $\mathrm{O}_{2}$ and SRP, primary productivity and burial of POC and reactive $\mathrm{P}$ to a $50 \%$ reduction in oceanic circulation, relative to the present ocean, for 3 scenario's: (1) standard (drawn line); (2) 20\% increase in river input of reactive P (weathering; short dash); (3) no redox-dependent reactive P and POC burial in the deep ocean (no redox; medium dash).

or directly followed periods of global ocean anoxia and increased organic carbon burial (Donnelly et al., 1990; Föllmi et al., 1993; Mazumdar et al., 1999). In other words, ancient phosphorites may in part reflect a global-scale, redoxdependent sink-switching, from the POP and FeP sinks in the deep ocean to the authigenic $\mathrm{CaP}$ sink on the shelves. Note that formation of phosphorite deposits also involves sediment reworking in order to concentrate the authigenic Ca-P (e.g. Filippelli and Delaney, 1992; Föllmi, 1996). Retention of reactive $\mathrm{P}$ on shelves may have been enhanced further during periods of sealevel rise (Compton et al., 2000; Wallmann, 2003).

\section{Conclusions}

Our model results suggest that a reduction in oceanic circulation results in a net transfer of soluble reactive phosphorus (SRP) from the open ocean to the coastal ocean, thereby increasing primary production and reactive $\mathrm{P}$ plus particulate organic C (POC) burial on the continental shelves. Because of the transfer of reactive $\mathrm{P}$ to the coastal ocean, the build-up of SRP in the deep-sea may not be sufficient to compensate for the reduced rate of oceanic upwelling, and open ocean primary production is expected to decrease. Burial of POC may nonetheless increase, because of enhanced POC preservation under anoxic conditions. Phosphorus-limited marine productivity and burial of POC are further stimulated when reduced oceanic circulation also causes the spreading of bottom water anoxia in the coastal ocean. These conditions are favorable to the large-scale accumulation of organic-rich sed- iments characterizing oceanic anoxic events (OAEs). In addition, the accompanying redistribution of reactive $\mathrm{P}$ burial from the open ocean organic- and iron-bound $\mathrm{P}$ sinks to the coastal ocean authigenic calcium phosphate sink may help explain the formation of massive phosphorite deposits that often coincide or follow OAEs.

Acknowledgements. This research was made possible by a fellowship of the Royal Netherlands Academy of Arts and Sciences (KNAW) to C. P. Slomp, and financial support from the Netherlands Organization for Scientific Research (Vidi grant to CPS and Pioneer grant to PVC). We thank C. Meile for technical support and helpful discussion.

Edited by: T. W. Lyons

\section{References}

Anderson, L. D., Delaney, M. L., and Faul, K. L.: Carbon to phosphorus ratios in sediments: Implications for nutrient cycling, Global Biogeochem. Cycles, 15, 65-79, 2001.

Arrigo, K. R.: Marine microorganisms and global nutrient cycles, Nature, 437, 349-355, 2005.

Berner, R. A.: Burial of organic carbon and pyrite sulfur in the modern ocean: its geochemical and environmental significance, Amer. J. Sci., 282, 451-473, 1982.

Berner, E. K. and Berner, R. A.: Global Environment: Water, Air and Geochemical Cycles, Prentice Hall, 376 pp., 1996.

Berner, R. A. and Rao, J. L.: Phosphorus in sediments of the Amazon River and estuary: implications for the global flux of phosphorus to the sea, Geochim. Cosmochim. Acta, 58, 2333-2340, 1994. 
Bjerrum, C. J. and Canfield, D. E.: Ocean productivity before about 1.9 Gyr ago limited by phosphorus adsorption onto iron oxides, Nature, 417, 159-162, 2002.

Bjerrum, C. J., Bendtsen, J., and Legarth, J. J. F.: Modeling organic carbon burial during sealevel rise with reference to the Cretaceous, Geochem., Geophys., Geosyst., 7, Q05008, doi:10.1029/2005GC001032, 2006.

Boudreau, B. P.: Diagenetic models and their implementation, Modelling transport and reactions in aquatic sediments, Springer, 414p, 1997.

Brink, K. H., Abrantes, F. F. G., Bernal, P. A., Dugdale, R. C., Estrada, M., Hutchings, L., Jahnke, R. A., Muller, P. J., and Smith, R. L.: How do coastal upwelling systems operate as integrated physical, chemical and biological systems and influence the geological record? The role of physical processes in defining the spatial structures of biological and chemical variables, in: Upwelling in the ocean: Modern processes and ancient records, edited by: Summerhayes, C. P., Emeis, K.-C., Angel, M. V., Smith, R. L., and Zeitschel, B., Wiley, 103-124, 1995.

Broecker, W. S.: Thermohaline circulation, the Achilles heel of our climate system: will man-made $\mathrm{CO}_{2}$ upset the current balance?, Science, 278, 1582-1588, 1997.

Butcher, S. S., Charlson, R. J., Orians, G. H., and Wolfe, G. V.: Global Biogeochemical Cycles, Academic Press, London, 377p, 1992.

Canfield, D. E.: Factors influencing organic carbon preservation in marine sediments, Chem. Geol., 114, 315-329, 1994.

Carman, R., Aigars, J., and Larsen, B.: Carbon and nutrient geochemistry of the surface sediments of the Gulf of Riga, Baltic Sea, Mar. Geol., 134, 57-76, 1996.

Chameides, W. L. and Perdue, E. M.: Biogeochemical Cycles: A Computer-Interactive Study of Earth System Science and Global Change, Oxford University Press, 240p, 1997.

Chen, C. T. A., Liu, K. K., and Macdonald, R.: Continental Margin Exchanges, in: Ocean Biogeochem., edited by: Fasham, J. R., Springer, 53-97, 2003.

Colman, A. S. and Holland, H. D.: The global diagenetic flux of phosphorus from marine sediments to the oceans: redox sensitivity and the control of atmospheric oxygen levels, SEPM Special Publication No. 66, 53-75, 2000.

Compton, J., Mallinson, D., Glenn, C. R., Filippelli, G., Föllmi, K., Shields, G., and Zanin, Y.: Variations in the global phosphorus cycle, SEPM Special Publication No. 66, 21-33, 2000.

Donnelly, T. H., Shergold, J. H., Southgate, P. N., and Barnes, C. J.: Events leading to global phosphogenesis around the Proterozoic/Cambrian boundary, in: Phosphorite Research and Development, edited by: Notholt, A. J. G. and Jarvis, I., Geol. Soc. Spec. Publ. 52, 273-287, 1990.

Erbacher, J., Thurow, J., and Littke, R.: Evolution patterns of radiolarian and organic matter variations: A new approach to identify sea-level changes in mid-Cretaceous pelagic environments, Geology, 24, 499-502, 1996.

Erbacher, J., Huber, B. T., Norris, R. D., and Markey, M.: Increased thermohaline stratification as a possible cause for an ocean anoxic event in the Cretaeceous period, Nature, 409, 325327, 2001

Filippelli, G. M.: Carbon and phosphorus cycling in anoxic sediments of the Saanich Inlet, British Columbia, Mar. Geol., 174, 307-321, 2001.
Filippelli, G. M. and Delaney, M. L.: Similar phosphorus fluxes in ancient phosphorite deposits and a modern phosphogenic environment, Geology, 20, 709-1495, 1992.

Filippelli, G. M. and Delaney, M. L.: Phosphorus geochemistry of equatorial Pacific sediments, Geochim. Cosmochim. Acta, 60, 1479-1495, 1996.

Föllmi, K. B.: The phosphorus cycle, phosphogenesis and marine phosphate-rich deposits, Earth Sci. Rev., 40, 55-124, 1996.

Föllmi, K. B., Weissert, H., and Lini, A.: Nonlinearities in phosphogenesis and phosphorus-carbon coupling and their implications for global change, in: Interactions of the $\mathrm{C}, \mathrm{N}, \mathrm{P}$ and $\mathrm{S}$ Biochemical Cycles and Global Change, edited by: Wollast, R., Mackenzie, F. T., and Chou, L., NATO ASI Series, I4, Springer, Berlin, 447-474, 1993.

Haedrich, R. L. and Merrett, N. R.: Production/biomass ratios, size frequencies, and biomass spectra in deep-sea demersal fishes, in: Deep-Sea Food Chains and the Global Carbon Cycle, edited by: Rowe, G. T. and Pariente, V., Kluwer, 157-182, 1992.

Hammond, D. E., Giordani, P., Berelson, W. M., and Polette, R.: Diagenesis of carbon and nutrients and benthic exchange in sediments of the Northern Adriatic Sea, Mar. Chem., 66, 53-79, 1999.

Handoh, I. C. and Lenton, T. M.: Periodic mid-Cretaceous oceanic anoxic events linked by oscillations of the phosphorus and oxygen biogeochemical cycles, Global Biogeochem. Cycles, 17, 1092, doi:10.1029/2003GB002039, 2003.

Hartnett, H., Keil, R. G., Hedges, J. I., and Devol, A. H.: Influence of oxygen exposure time on organic carbon preservation in continental margin sediments, Nature, 391, 572-574, 1998.

Hedges, J. I., Hu, F. S., Devol, A. H., Hartnett, H. E., Tsamakis, E., and Keil, R. G.: Sedimentary organic matter preservation: A test for selective degradation under oxic conditions, Amer. J. Sci., 299, 529-555, 1999.

Holland, H. D.: The Chemical Evolution of the Atmosphere and Oceans, New York, Wiley, 598p, 1984.

Hotinski, R., Kump., L. R., and Najjar, R. G.: Opening Pandora's Box: the impact of open system modeling on interpretations of anoxia, Paleoceanography, 15, 267-279, 2000.

Howarth, R. W., Jensen, H. S., Marino, R., and Postma, H.: Transport to and processing of $\mathrm{P}$ in near-shore and oceanic waters, in: Phosphorus in the global environment, edited by: Tiessen, H., Transfers, cycles and Management, SCOPE 54, Wiley, 323-345, 1995.

Ingall, E. D. and Van Cappellen, P.: Relation between sedimentation rate and burial of phosphorus and organic carbon in marine sediments, Geochim. Cosmochim. Acta, 54, 373-386, 1990.

Ingall, E. D. and Jahnke, R. A.: Influence of water-column anoxia on the elemental fractionation of carbon and phosphorus during sediment diagenesis, Mar. Geol., 139, 219-229, 1997.

Ingall, E. D., Bustin, R. M., and Van Cappellen, P.: Influence of water column anoxia on the burial and preservation of carbon and phosphorus in marine shales, Geochim. Cosmochim. Acta, 57, 303-316, 1993.

Ingall, E., Kolowith, L., Lyons, T., and Hurtgen, M.: Sediment carbon, nitrogen and phosphorus cycling in an anoxic fjord, Effingham Inlet, British Columbia, Amer. J. Sci., 905, 240-258, 2005.

Intergovernmental Panel on Climate Change (IPCC): Climate Change 2001, in: The Scientific Basis, edited by: Houghton, J. T., Ding, Y., Griggs, D. J., Noguer, M., et al., Cambridge Univer- 
sity Press, 2001.

Jahnke, R. A.: The phosphorus cycle, in: Global Biogeochem. Cyc., edited by: Butcher, S. S., Charlson, R. J., Orians, G. H., and Wolfe, G. V., Academic Press, London, 301-315, 1992.

Kolonic, S., Wagner, T., Forster, A., Damste, J. S. S., WalsworthBell, B., Erba, E., Turgeon, S., Brumsack, H. J., Chellai, E. I., Tsikos, H., Kuhnt, W., and Kuypers, M. M. M.: Black shale deposition on the northwest African Shelf during the Cenomanian/Turonian oceanic anoxic event: Climate coupling and global organic carbon burial, Paleoceanography, 20, PA1006, doi:10.1029/2003PA000950, 2005.

Kuypers, M. M. M.: Mechanisms and biogeochemical implications of the mid-Cretaceous global organic carbon burial events, $\mathrm{PhD}$ thesis, Utrecht University, 135 pp, 2001.

Kuypers, M. M. M., Pancost, R. D., Nijenhuis, I. A., and Sinnighe Damste, J. S.: Enhanced productivity led to increased organic carbon burial in the euxinic North Atlantic basin during the late Cenomanian oceanic anoxic event, Paleoceanography, 17, 1051, doi:10.1029/2000PA000569, 2002.

Lasaga, A. C.: The kinetic treatment of geochemical cycles, Geochim. Cosmochim. Acta, 44, 815-828, 1980.

Mackenzie, F. T., Ver, L. M., Sabine, C., Lane, M., and Lerman, A.: C, N, P, S Global biogeochemical cycles and modeling of global change, in: Interactions of $\mathrm{C}, \mathrm{N}, \mathrm{P}$ and $\mathrm{S}$ biogeochemical cycles and global change, edited by: Wollast, R., Mackenzie, F. T., and Chou, L., Springer, Berlin, 1993.

Mackenzie, F. T., Ver, L. M., and Lerman, A.: Coupled biogeochemical cycles of carbon, nitrogen, phosphorus and sulfur in the land-ocean-atmosphere system, in: Asian change in the context of global climate change, edited by: Galloway, J. N. and Mellillo, J. M., Cambridge University Press, 42-100, 1998.

Mazumdar, A., Banerjee, D. M., Schidlowski, M., and Balkaram, V.: Rare-earth elements and stable isotope geochemistry of early Cambrian chert-phosphorite assemblages from the Lower tal Formation of the Krol Belt (Lesser Himalaya, India), Chem. Geol., 156, 275-297, 1999.

Meile, C. and Van Cappellen, P.: Particle age distributions and O2 exposure times: timescales in bioturbated sediments, Global Biogeochem. Cycles, 19(3), GB3013, doi:10.1029/2004GB002371, 2005.

Nederbragt, A. J., Thurow, J., Vonhof, H., and Brumsack, H.-J.: Modelling oceanic carbon and phosphorus fluxes: implications for the cause of the late Cenomanian Oceanic Anoxic Event (OAE2), Journal of the Geological Society of London, 161, 721728, 2004

Neretin, L. N., Bottcher, M. E., and Grinenko, V. A.: Sulfur isotope geochemistry of the Black Sea water column, Chem. Geol., 200, 59-69, 2003.

Pauly, D. and Christensen, V.: Primary production required to sustain global fisheries, Nature, 374, 255-257, 1995.

Petsch, S. T. and Berner, R. A.: Coupling the geochemical cycles of $\mathrm{C}, \mathrm{P}, \mathrm{Fe}$, and $\mathrm{S}$ : the effect on atmospheric $\mathrm{O}_{2}$ and the isotopic records of carbon and sulfur, Amer. J. Sci., 298, 246-262, 1998.

Rabouille, C., Mackenzie, F. T., and Ver, L. M.: Influence of the human perturbation on carbon, nitrogen, and oxygen biogeochemical cycles in the global coastal ocean, Geochim. Cosmochim. Acta, 65, 3615-3641, 2001.

Rahmstorf, S.: Ocean circulation and climate during the past 120000 years, Nature, 419, 207-214, 2002.
Ruttenberg, K. C.: Reassessment of the oceanic residence time of phosphorus, Chem. Geol., 107, 405-409, 1993.

Ruttenberg, K. C. and Berner, R. A.: Authigenic apatite formation and burial in sediments from non-upwelling, continental margin environments, Geochim. Cosmochim. Acta, 57, 991-1007, 1993.

Sarmiento, J. L., Herbert, T. D., and Toggweiler, J. R.: Causes of anoxia in the world ocean, Global Biogeochem. Cycles, 2, 115$128,1988$.

Schenau, S. J.: Cycling of phosphorus and manganese in the Arabian Sea during the late Quaternary, Geologica Ultraiectina, No. 182, Utrecht University, 184p, 1999.

Schenau, S. J. and de Lange, G. J.: A novel chemical method to quantify fish debris in marine sediments, Limnol. Oceanogr., 45, 963-971, 2000.

Schenau, S. J. and de Lange, G. J.: Phosphorus regeneration vs. burial in sediments of the Arabian Sea, Mar. Chem., 75, 201207, 2001.

Schenau, S. J., Slomp, C. P., and de Lange, G. J.: Phosphogenesis and phosphorite formation in sediments located within the Arabian Sea Oxygen Minimum Zone, Mar. Geol., 169, 1-20, 2000.

Schlanger, S. O. and Jenkyns, H. C.: Cretaceous oceanic anoxic events: causes and consequences, Geologie en Mijnbouw, 55, 179-184, 1976.

Slomp, C. P., Epping, E. H. G., Helder, W., and van Raaphorst, W.: A key role for iron-bound phosphorus in authigenic apatite formation in North Atlantic continental platform sediment, J. Mar. Res., 54, 1179-1205, 1996.

Slomp, C. P., Malschaert, J. F. P., and van Raaphorst, W.: The role of sorption in sediment-water exchange of phosphate in North Sea continental margin sediments, Limnol. Oceanogr., 43, 832-846, 1998.

Slomp, C. P., Thomson, J., and de Lange, G. J.: Enhanced regeneration of phosphorus during formation of the most recent eastern Mediterranean sapropel (S1), Geochim. Cosmochim. Acta, 66, 1171-1184, 2002.

Slomp, C. P. and Van Cappellen, P.: Groundwater inputs of nutrients to the coastal ocean: controls and potential impact, J. Hydrol., 295, 64-86, 2004.

Slomp, C. P., Thomson, J., and de Lange, G. J.: Controls on phosphorus regeneration and burial during formation of eastern Mediterranean sapropels, Mar. Geol., 203, 141-159, 2004.

Tamburini, F., Huon, S., Steinmann, P., Grousset, F. E., Adatte, T., and Follmi, K. B.: Dysaerobic conditions during Heinrich events 4 and 5: Evidence from phosphorus distribution in a North Atlantic deep-sea core, Geochim. Cosmochim. Acta, 66, 40694083, 2002.

Tyrell, T.: The relative influence of nitrogen to phosphorus on oceanic primary production, Nature, 400, 525-531, 1999.

Van Cappellen, P. and Ingall, E. D.: Benthic phosphorus regeneration, net primary production, and ocean anoxia: A model of the coupled marine biogeochemical cycles of carbon and phosphorus, Paleoceanography, 9, 677-692, 1994.

Van Cappellen, P. and Ingall, E. D.: Redox stabilization of the atmosphere and oceans by phosphorus-limited marine productivity, Science, 271, 493-496, 1996.

Van Cappellen, P. and Wang, Y. F.: Cycling of iron and manganese in surface sediments: a general theory for the coupled transport and reaction of carbon, oxygen, nitrogen, sulfur, iron, and manganese, Amer. J. Sci., 296, 197-243, 1996. 
Van Cappellen, P. and Ingall, E. D.: Response to Comment "Redox stabilization of the atmosphere and oceans and marine productivity" by Colman, A. S., Mackenzie, F. T., Holland, H. D., Science, 275, 407-408, 1997.

Van Cappellen, P. and Slomp, C. P.: Phosphorus burial in marine sediments, Honolulu, Hawaii, Proceedings of the Sixth International Symposium on the Geochemistry of the Earth's Surface, International Association of Geochemistry and Cosmochemistry, 239-244, 2002.

Ver, L. M. B., Mackenzie, F. T., and Lerman, A.: Biogeochemical responses of the carbon cycle to natural and human perturbations: past, present, and future, Amer. J. Sci., 299, 762-801, 1999.
Wallmann, K.: Feedbacks between oceanic redox states and marine productivity: A model perspective focused on benthic phosphorus cycling, Global Biogeochem. Cycles, 17, 1084, doi:10.1029/2002GB001968, 2003.

Walsh, J. J.: Importance of continental margins in the marine biogeochemical cycling of carbon and nitrogen, Nature, 350, 53-55, 1991.

Wollast, R.: Interactions of carbon and nitrogen cycles in the coastal zone, in: Interactions of $\mathrm{C}, \mathrm{N}, \mathrm{P}$ and $\mathrm{S}$ biogeochemical cycles and global change, edited by: Wollast, R., Mackenzie, F. T., and Chou, L., Springer, Berlin, 195-210, 1993. 